\title{
27. FABRIC OF FINE-GRAINED AMAZON FAN SEDIMENTS: INFLUENCE OF DEPOSITIONAL PROCESSES AND BURIAL TRANSFORMATION ${ }^{1}$
}

\author{
William H. Busch² and Michael R. Brister ${ }^{2}$
}

\begin{abstract}
Fine-grained sediments from six sites on the Amazon Fan were examined to determine the relationship between the fabric and physical properties of the sediments and the extent to which the fabric reflects the influence of depositional processes and burial-related change. Secondary and backscattered electron imaging with a scanning electron microscope were used to examine samples selected from proximal levee, bioturbated mud, distal levee, and mass-transport deposits (MTDs). The distal levee sediments display less variable particle orientations than proximal levee deposits and a greater particle reorientation with burial. Fine-grained MTDs are characterized by a variety of fabrics, including randomly oriented clay domains and silt grains, very dense fabrics in displaced sediment blocks, and fabrics reflecting zones of shearing and sediment deformation. Anisotropy of electrical resistivity provides an independent measure of sediment fabric and a means to distinguish levee and MTDs. The correspondence between resistivity measurements and electron microscope fabric observations is weak. In all sediment types, the greatest change in fabric occurs at depths less than $50 \mathrm{~m}$ below the seafloor as a result of the collapse of a porous, open fabric to yield a more dense particle arrangement with larger clay domains and reduced porosity. As burial depth increases, the fabric progressively becomes denser, but the transformation occurs at a slower rate than the change at shallow depths. The reduction in bulk porosity matches the rate of fabric change with depth. Because of the variety of fabrics that occur in the masstransport units, it is difficult to determine what aspect of these deposits is responsible for anomalously high porosity that is common in underlying sediments.
\end{abstract}

\section{INTRODUCTION}

Silty clays and clayey silts comprise the bulk of the sediments recovered from the Amazon Fan during Leg 155. These fine-grained sediments occur in a variety of forms, including bioturbated and color-banded intervals, structureless muds with few silt laminae, muds interbedded with silt laminae and silt and sand beds of varying thicknesses, the matrix of debris-flow deposits, and displaced blocks within mass-transport deposits (MTDs). Because of the fine-grain size, it is often difficult to visually discern differences among these sediments. As a result, electron microscopy studies of the microstructure of fine-grained sediments play an important role in determining the physical characteristics of these materials (Bennett et al., 1991a). The objective of this study is to determine the relationships between finegrained sediment fabric and depositional processes, burial transformation, and sediment physical properties. The importance of establishing these relationships is to characterize differences between the major sediment types on the fan and to provide insight into how the processes of fan growth and postdepositional modification influence the variation of sediment physical properties. Sediments from six sites on the Amazon Fan (Sites 930, 931, 933, 935, 938, and 941; Fig. 1) were examined using techniques of secondary electron (SE) and backscattered electron (BSE) imaging with a scanning electron microscope (SEM). Samples were selected from generalized facies identified as proximal levee, bioturbated mud, distal levee, and mass transport (Flood, Piper, Klaus, et al., 1995) to provide a range in depositional settings. In addition, samples were selected to encompass the range of depths, ages, and physical properties sampled during Leg 155 .

${ }^{1}$ Flood, R.D., Piper, D.J.W., Klaus, A., and Peterson, L.C. (Ed.), 1997. Proc. ODP, Sci. Results, 155: College Station, TX (Ocean Drilling Program).

${ }^{2}$ Department of Geology and Geophysics, University of New Orleans, New Orleans, LA 70148, U.S.A. busch@ geology.uno.edu

\section{GENERAL CHARACTERISTICS OF FABRIC SAMPLES}

Select physical properties and sediment characteristics of the fabric samples are summarized in Table 1 . The six sites sampled include (1) Site 930, located on the upper part of the Amazon Fan on the crest of the buried Orange Levee, west of the active Amazon Channel in a topographic low formed between the Purple and Amazon Levees; (2) Site 931, located on a flat terrace on the western levee of the buried Channel 5 system; (3) Site 933, located on the eastern part of the fan, on the flank of the eastern levee of the Yellow Channel system; (4) Site 935, located on the flank of the Aqua Channel system; (5) Site 938 , located on the eastern side of the fan, on the flank of the western levee of the Blue Channel-levee System; and (6) Site 941, located on a surficial debris-flow deposit between two levees on the western part of the fan. The burial depth of the samples ranges from 2.65 to 367.79 meters below seafloor (mbsf). The bulk of the muds examined are late Pleistocene in age. Middle Pleistocene levee deposits were sampled at Sites 933 and 935.

Fine-grained sediment fabric varies as a function of variations in clay mineralogy and organic content (Pusch, 1973; Mitchell, 1976; Bennett et al.,1991b). Because of the relative uniformity in the composition of the fine-grained sediments on the Amazon Fan, it is assumed that these factors minimally influence fabric variations. Quantitative determinations of clay mineral abundances from several sites on the fan indicate a relatively homogeneous mixture of smectite $(20 \%-45 \%)$, illite $(20 \%-35 \%)$, kaolinite $(15 \%-25 \%)$, and chlorite (8\%-15\%) (Debrabant et al., this volume). Organic carbon and carbonate contents are uniformly low in the fine-grained terrigenous sediments on the fan. Organic carbon content typically ranges from $0.5 \%$ to $1 \%$, and the calcium carbonate percentages generally vary between $1 \%$ and 5\% (Flood, Piper, Klaus, et al., 1995).

The grain size of the fine-grained sediments of the Amazon Fan varies within a relatively narrow range. Size analyses of residues from physical properties measurements (Manley et al., this volume) show 


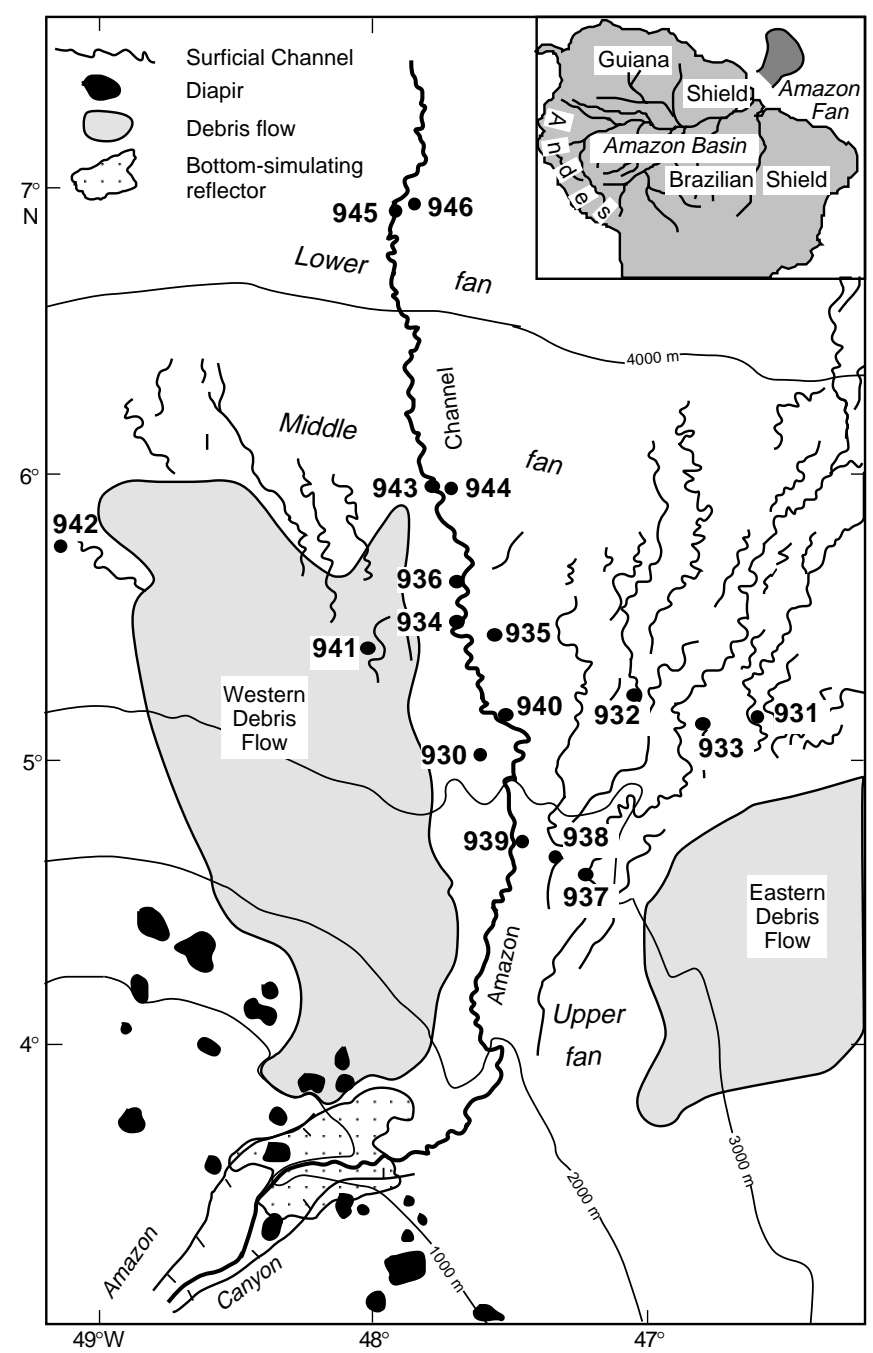

Figure 1. Generalized map of the Amazon Fan showing the location of Leg 155 drill sites. From Flood et al., 1995; modified from Damuth et al., 1988, and Manley and Flood, 1988.

that these samples, selected from "clay-rich" intervals, primarily are composed of silt-sized particles. The fine-grained samples from the upper part of the fan typically contain 5\%-20\% clay, 70\%-85\% silt, and $0 \%-10 \%$ sand. The average modal size of these sediments ranges from 4 to $11 \mu \mathrm{m}$.

Variation of physical properties at the sites drilled during Leg 155 is characterized by regular trends common among the sites. An exponential downhole decrease in porosity characterizes the fine-grained sediments deposited on the levees. The composite porosity profile for Sites 930, 931, 935, and 938 (Fig. 2) shows that porosity decreases rapidly in the first $50 \mathrm{mbsf}$. The decrease is from $\sim 75 \%$ at the seafloor to $60 \%$ at $25 \mathrm{mbsf}$ and $56 \%$ at $50 \mathrm{mbsf}$. Below $50 \mathrm{mbsf}$, the slowing in the rate of porosity decrease is shown in the composite profile by porosities of $\sim 53 \%$ at $100 \mathrm{mbsf}$ and $48 \%$ at $300 \mathrm{mbsf}$ (Fig. 2). The fine-grained sediments of debris-flow and MTDs are characterized by porosities lower than those of the levee deposits. A composite porosity profile for MTDs from Sites 930, 931, 935, and 941 (Fig. 3) shows that, at comparable depths, between the seafloor and $150 \mathrm{mbsf}$, the porosity of the mass-transport sediments is $\sim 3 \%-5 \%$ less than that of the levee deposits. Below 200 mbsf, this porosity difference increases slightly to $5 \%-7 \%$. Porosity in the mass-transport intervals typically is more variable than it is in other intervals, a characteristic attributed to the mixture of sediment types incorporated in the MTDs. Beneath the MTDs, it is common for the levee sediments to display a higher than expected porosity, suggesting a slight overpressuring of these formations (Flood, Piper, Klaus, et al., 1995).

Variations in electrical resistivity may provide insight into the fabric of the fine-grained sediments. The resistivity was calculated from resistance measurements made perpendicular and parallel to bedding. Resistivity anisotropy was calculated, from these two sets of measurements, as the difference between the transverse (parallel to bedding) and longitudinal (perpendicular to bedding) resistivity divided by the mean resistivity, and expressed as a percentage. A common characteristic of the resistivity measurements from the Amazon Fan is that sediments from well-bedded levee sequences display a negative resistivity anisotropy, and the debris-flow deposits are isotropic or display widely varying anisotropy. The significance of the negative anisotropy is that it reflects a greater electrical resistance in the vertical direction than the horizontal direction, which may be attributed to greater alignment of sediment particles parallel to bedding.

The resistivity of the core samples was measured using a small four-probe configuration that was inserted $\sim 2 \mathrm{~mm}$ into the split core surface. The resistivity was determined from the potential drop between two electrodes with a $0.15-\mathrm{mm}$ spacing. The dimensions of the probe are important for considering the scale of the anisotropy and the potential influence of sediment disturbance.

\section{METHODS}

Samples for fabric analysis were obtained on the JOIDES Resolution shortly after core sections were split. The samples were taken adjacent to samples used to determine physical properties. Sampling involved pushing a polystyrene "paleomag" cube $(2 \times 2 \times 1.5 \mathrm{~cm})$ into the sediment and extracting it in such a way as to minimize sample disturbance. Sample cubes were marked for bedding orientation, sealed to be airtight, and stored at $4^{\circ} \mathrm{C}$. Care was taken to maintain the sample moisture content to minimize possible fabric disruption accompanying desiccation. Samples were extracted by cutting away the polystyrene cubes. Depending on the stiffness of the sample, the sediment cube was cut in half using a fine wire or razor blade. One half of the sample was prepared for SE imaging, and the other half was prepared for BSE imaging. During the extraction and subsequent preparation for SEM examination, identification of bedding orientation was maintained.

Secondary electron imaging, the more common use of the SEM, was used to obtain a three-dimensional view of sediment topography, typically at magnifications of $1000 \times-4000 \times$. Freshly fractured surfaces of dried sample cubes $\sim 5 \mathrm{~mm}$ on a side were used for SE imaging. The samples were dehydrated by critical-point drying using the procedure of Bennett et al. (1977). Dried samples were mounted on SEM stubs with the bedding nearly perpendicular to the surface of the stub. The samples were notched with a razor blade and fractured. Loose particles were cleaned from the fractured surface using the electrostatic technique of Hulbert and Bennett (1975). Immediately after the cleaning, the samples were coated, first with carbon and then with gold.

Backscattered electron imaging of polished sections provided a two-dimensional view useful for examining particle shapes and orientations at magnifications of $100 \times-500 \times$. Polished sections were prepared by impregnating samples with "L.R. White" resin, an ultralow viscosity acrylic resin that can impregnate samples dehydrated with ethanol. Sample preparation followed the procedure of Bennett et al. (1977) through immersion in $100 \%$ ethanol. Following immersion in ethanol, the samples were placed in a $2: 1$ L.R. White/ethanol solution. After two days in this solution, the samples were placed in a polyethylene capsule filled with $100 \%$ L.R. White. The samples re- 
Table 1. Select physical properties and sediment characteristics of fabric samples.

\begin{tabular}{|c|c|c|c|c|c|c|c|}
\hline $\begin{array}{l}\text { Core, section, } \\
\text { interval }(\mathrm{cm})\end{array}$ & $\begin{array}{l}\text { Depth } \\
\text { (mbsf) }\end{array}$ & $\begin{array}{l}\text { Porosity } \\
(\%)\end{array}$ & $\begin{array}{l}\text { Grain } \\
\text { density } \\
\left(\mathrm{g} / \mathrm{cm}^{3}\right)\end{array}$ & $\begin{array}{l}\text { Resistivity } \\
\text { anisotropy } \\
(\%)\end{array}$ & $\begin{array}{c}\text { Acoustic } \\
\text { stratigraphic } \\
\text { unit }\end{array}$ & $\begin{array}{l}\text { Sediment } \\
\text { facies }\end{array}$ & Description \\
\hline \multicolumn{8}{|r|}{ 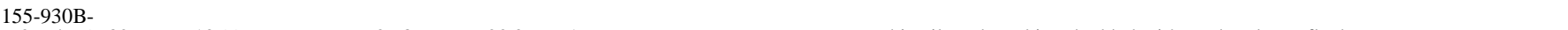 } \\
\hline $2 \mathrm{H}-4,79-82$ & 10.99 & 66 & 2.78 & -20.0 & Aqua & DL & Thin silt and sand interbedded with mud on levee flank \\
\hline $11 \mathrm{H}-4,26-28$ & 95.96 & 50 & 2.69 & 0.5 & Blue/Yellow & DL & Color-banded or bioturbated mud on levee flank \\
\hline $19 X-5,43-45$ & 173.76 & 50 & 2.83 & -13.9 & Orange & PL & Thin-bedded silt and sand with mud on levee crest \\
\hline $24 X-3,27-29$ & 218.97 & 36 & 2.75 & 6.6 & Orange & DF & Mass-transport deposit \\
\hline \multicolumn{8}{|l|}{ 155-930C- } \\
\hline $17 \mathrm{X}-1,100-102$ & 240.70 & 54 & 2.49 & 7.2 & Orange & DF & Mass-transport deposit \\
\hline $\begin{array}{l}155-931 \mathrm{~A}- \\
1 \mathrm{H}-3,34-36\end{array}$ & 3.34 & 71 & 2.95 & 6.4 & Amazon/Yellow & $\mathrm{BM}$ & Levee flank bioturbated and color-banded mud \\
\hline \\
\hline $12 \mathrm{X}-3,87-89$ & 97.77 & $\begin{array}{l}58 \\
53\end{array}$ & $\begin{array}{l}2.80 \\
2.67\end{array}$ & $\begin{array}{r}1.0 \\
-2.2\end{array}$ & Channel 5 & $\begin{array}{l}\text { PL } \\
\text { PL }\end{array}$ & $\begin{array}{l}\text { Mud with silt laminae and thin silt beds on levee crest } \\
\text { Mud with thin to thick silt and fine sand beds on levee crest }\end{array}$ \\
\hline \multicolumn{8}{|l|}{$155-933 \mathrm{~A}-$} \\
\hline $20 \mathrm{X}-3,83-85$ & 180.73 & 52 & 2.79 & 2.6 & $\begin{array}{l}\text { Bottom Levee } \\
\text { Complex }\end{array}$ & PL & Mud with silt laminae on levee crest \\
\hline \multicolumn{8}{|l|}{ 155-935A- } \\
\hline $1 \mathrm{H}-2,115-117$ & 2.65 & 75 & 2.71 & -1.1 & Amazon/Brown & $\mathrm{BM}$ & Bioturbated mud from the Amazon Channel \\
\hline $4 \mathrm{H}-3,77-80$ & 26.27 & 62 & 2.76 & 0.5 & Aqua & PL & Mud with infrequent silt laminae and thin silt/sand beds on levee crest \\
\hline $10 \mathrm{H}-6,83-85$ & 87.04 & 53 & 2.73 & -1.3 & Aqua & PL & Mud with frequent silt laminae and thin silt/sand beds on levee crest \\
\hline $12 \mathrm{H}-4,109-111$ & 104.09 & 51 & 2.78 & -7.8 & Aqua & PL & Mud with thick beds of medium sand and thin beds of silt and sand on levee crest \\
\hline $25 X-2,46-49$ & 220.56 & 46 & 2.76 & -19.1 & Unit R & DF & Mass-transport deposit \\
\hline $31 X-5,67-69$ & 282.34 & 47 & 2.74 & 1.0 & Green & $\mathrm{CC}$ & Interglacial calcareous clay \\
\hline $40 \mathrm{X}-4,29-31$ & 367.79 & 47 & 2.80 & -3.8 & Green & PL & Mud with laminae and thin beds of silt and fine sand on levee crest \\
\hline \multicolumn{8}{|l|}{$155-938 \mathrm{~A}-$} \\
\hline $1 \mathrm{H}-3,50-52$ & 3.50 & 70 & 2.68 & -2.5 & Amazon/Purple & BM & Bioturbated mud from distant active channel system \\
\hline $11 X-2,55-57$ & 95.15 & 54 & 2.72 & -6.9 & Blue & PL & Mud with abundant laminae and thin beds of silt/sand on levee flank \\
\hline $22 \mathrm{X}-3,100-102$ & 200.50 & 50 & 2.71 & -0.8 & Channel 5/Yellow & DL & $\begin{array}{l}\text { Mud with abundant laminae and thin beds of silt/sand filling an abandoned } \\
\text { channel }\end{array}$ \\
\hline $28 \mathrm{X}-4,108-110$ & 256.98 & 49 & 2.77 & 1.0 & Channel 6 & PL & Mud with laminae and thin beds of silt and sand on levee crest \\
\hline $33 \mathrm{X}-3,60-62$ & 303.10 & 47 & 2.82 & 3.1 & Channel 6 & PL & Mud with laminae and thin beds of silt and sand on levee crest \\
\hline \multicolumn{8}{|l|}{ 155-941B- } \\
\hline $2 \mathrm{H}-2,75-77$ & 8.85 & 61 & 2.77 & -3.5 & Western Debris Flow & $\mathrm{DF}$ & Mass-transport deposit \\
\hline $7 \mathrm{H}-5,123-125$ & 56.83 & 49 & 2.78 & -8.2 & Western Debris Flow & DF & Mass-transport deposit \\
\hline $11 \mathrm{H}-5,86-88$ & 80.07 & 51 & 2.72 & 0.8 & Western Debris Flow & $\mathrm{DF}$ & Mass-transport deposit \\
\hline
\end{tabular}

Note: $\mathrm{DL}=$ distal levee $; \mathrm{PL}=$ proximal levee $\mathrm{DF}=$ debris flow $\mathrm{BM}=$ bioturbated mud and $\mathrm{CC}=$ calcareous clay.

mained in the resin at room temperature for one day. The resin was polymerized by thermal curing at $60^{\circ} \mathrm{C}$ for $20-24 \mathrm{hr}$. Two sections, at $90^{\circ}$ to each other, were cut from the samples and polished using a lapping wheel impregnated with 15 - $\mu \mathrm{m}$-diameter diamonds. The sections were carbon-coated as a final preparation for viewing with the BSE detector.

Particle orientations were determined quantitatively from BSE images. Negatives of the images were scanned and imported into BioScan Optimas, a PC-based image analysis software package. The gray-level threshold was set to highlight the silt particles, which appear white, or light gray, on a positive print. The size of the particles measured for orientation was varied to yield $\sim 250$ particles per data set. The orientation and length of the long axis of the particles were determined. Optimas identifies a long axis by first fitting a polygon about the highlighted particle, and then determining the major axis of the polygon. The angle of the long axis is measured counterclockwise from the horizontal, from $0^{\circ}$ to $360^{\circ}$. These data were plotted as bidirectional data on an equal-area rose diagram, and statistical parameters were calculated.

\section{FABRIC OBSERVATIONS}

Descriptions of the fine-grained sediment fabric are divided into three groupings that reflect the general characteristics and depositional setting of the sediments. Proximal levee deposits consist of mud with abundant silt laminae and thin beds of silt and sand. These sediments were deposited adjacent to active channel systems. Bioturbated mud and distal levee deposits are grouped together and represent sediments deposited more distant from the active channels, or during periods of higher sea level and reduced fan sedimentation.
Bioturbated or color-banded mud, or structureless mud with infrequent silt laminae and beds, characterize these deposits. A mixture of features characterize the mass-transport facies. Color banding, contorted laminae and beds of silt and sand, clay clasts, displaced sediment blocks, and thick sand beds comprise these deposits.

\section{Proximal Levee Sediments}

The fabric of fine-grained, proximal levee sediments was examined over a depth range of 26.27-367.79 mbsf. The samples are from the late Pleistocene Upper Levee Complex (Aqua, Blue, Orange, Channel 5, and Channel 6) and the middle Pleistocene Lower Levee Complex (Green) and Bottom Levee Complex. The range in porosity represented by these samples is from 62\% (Sample 155-935A-4H-3, $77-80 \mathrm{~cm}$ ) at $26.27 \mathrm{mbsf}$ to $46 \%$ (Sample 155-935A-40X-4, 29-31 $\mathrm{cm})$ at $367.79 \mathrm{mbsf}$. The resistivity anisotropy varies between $3.1 \%$ and $-13.9 \%$ (Table 1 ).

The downhole changes in fine-grained sediment fabric for the proximal levee sediments reflect the general downhole trend in porosity. The shallowest sample, Sample $155-935 \mathrm{~A}-4 \mathrm{H}-3,77-80 \mathrm{~cm}$, is characterized by an open fabric with large (10-20 $\mu \mathrm{m}$ ) pores (Fig. 4). Clay domains, arrays of clay particles in face-to-face arrangements (Bennett and Hulbert, 1986), are small and grouped as loosely clustered flocs. The BSE image shows fine to coarse silt grains with an average long axis length $\left(\bar{d}_{\max }\right)$ of $15.0 \mu \mathrm{m}$. The silt particles appear to be floating in a clay matrix and lack a strong preferred orientation, although they do possess several structural features. These features include a roughly circular ring and thin bands of silt grains (Fig. 4). Sample 155-938A-11X-2, 55-57 cm, from $95.15 \mathrm{mbsf}$, has a bulk porosity of $54 \%$. This $8 \%$ reduction in porosity from that of Sample $155-935 \mathrm{~A}-4 \mathrm{H}-3,77-80 \mathrm{~cm}$, is expressed as a denser fabric with 


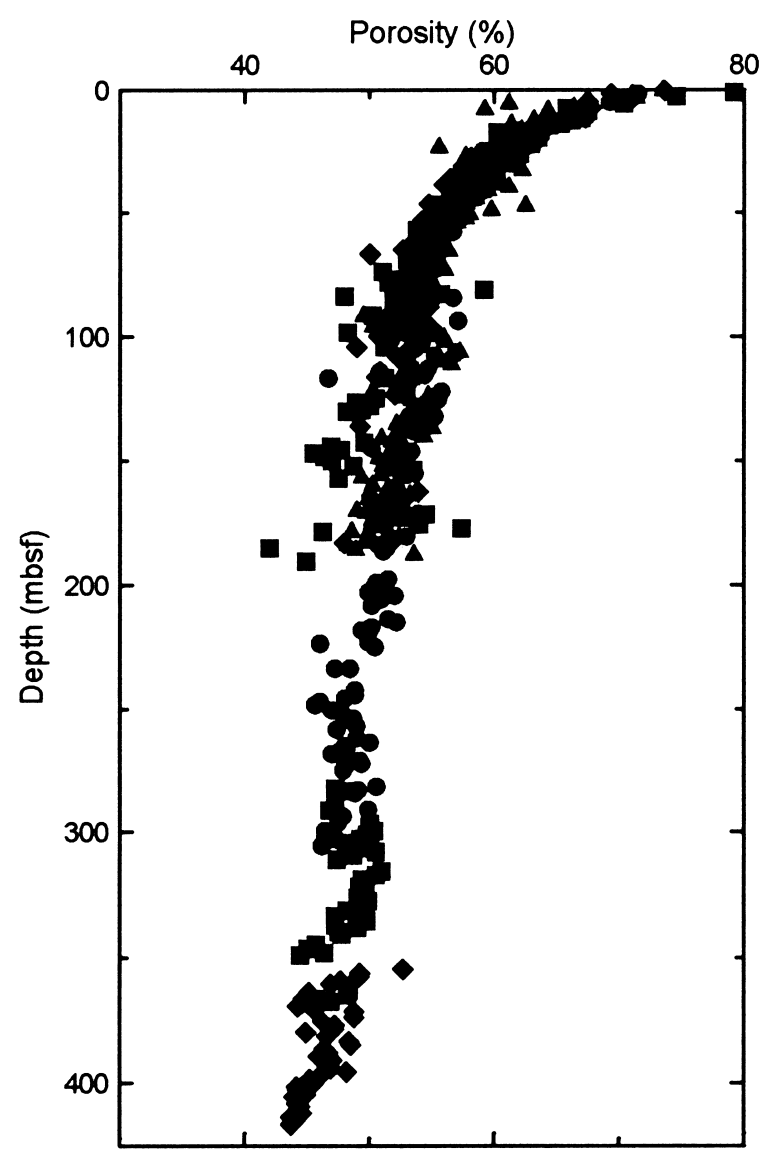

Figure 2. Composite porosity profile for silty clays and clayey silts from levee deposits at Sites 930 (triangle), 931 (diamond), 935 (square), and 938 (circle).

smaller pores that are more difficult to distinguish (Fig. 5). Clay domains are larger in Sample 155-938A-11X-2, 55-57 cm, and exhibit a more compacted appearance with a tendency for preferred, parallel orientation. The porosity of Sample 155-933A-20X-3, 83-85 cm, at $180.73 \mathrm{mbsf}$, is $52 \%$. Domains in this sample are more compacted and difficult to distinguish from silt particles (Fig. 6). A crude alternation of coarse and fine silt is displayed in the BSE image. Sample 155-933A-20X-3, 83-85 cm, is from the middle Pleistocene Bottom Levee Complex and is the oldest sediment examined. Sample 155935A-40X-4, 29-31 cm, represents the sample from the greatest burial depth, 367.79 mbsf. The porosity of this sample is low, $46 \%$, and the fabric is dense with closely spaced clay domains and silt particles and few visible pores (Fig. 7). A roughly bedding-parallel alignment characterizes the SE image; however, more variable particle orientations are displayed in the BSE image (Fig. 7). The spacing of silt particles in the BSE image is noticeably reduced from the spacing in Samples 155-935A-4H-3, 77-80 cm, and 155-933A-20X-3, $83-85 \mathrm{~cm}$.

The trend in particle orientations measured for the proximal levee sediments is problematic. The circular variance $\left(s^{2}\right)$ can be used to compare the variability of the orientations. It has a potential range from 0 (all measurements in one direction) to 1 (random orientation) (Swan and Sandilands, 1995). The shallow sample, Sample 155935A-4H-3, 77-80 cm, is characterized by highly variable silt orientations and an $s^{2}$ value of 0.89 . As might be expected, the more deeply buried Sample 155-933A-20X-3, 83-85 cm, displays a mean silt orientation that is more nearly horizontal and a lower variability, $s^{2}=$ 0.69. Somewhat surprisingly, silt grain orientations are more variable in the deepest sample, Sample 155-935A-40X-4, 29-31 cm. At 0.86,

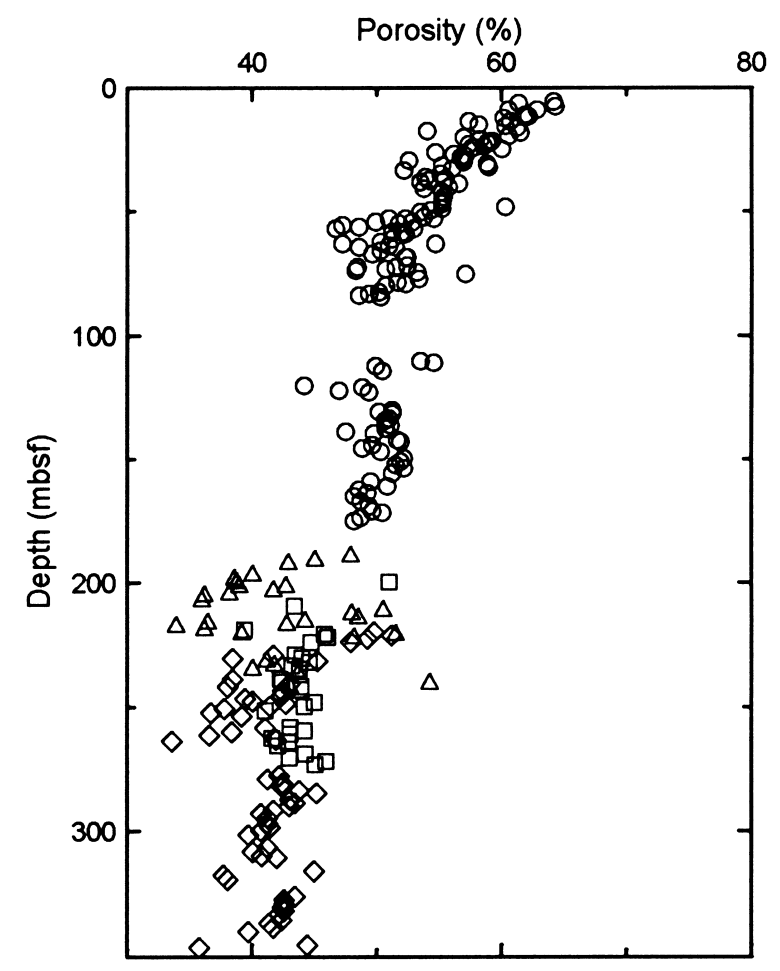

Figure 3. Composite porosity profile for fine-grained sediments from debrisflow and mass-transport intervals at Sites 930 (triangle), 931 (diamond), 935 (square), and 941 (circle).

the value of $s^{2}$ for this sample is comparable with that of the much more shallow buried Sample 155-935A-4H-3, 77-80 cm.

\section{Bioturbated Muds and Distal Levee Sediments}

The fabric of fine-grained bioturbated muds and distal levee sediments was examined over a depth range of 2.65-282.34 mbsf. This range includes samples from the Upper Levee Complex (Amazon, Brown, Aqua, Blue, Yellow, Orange, and Channel 5) and Lower Levee Complex (Green). The porosity of these sediments ranges from $74 \%$ (Sample 155-935A-1H-2, 115-117 cm) to $46 \%$ (Sample $155-935 \mathrm{~A}-31 \mathrm{X}-5,67-69 \mathrm{~cm})$. Resistivity anisotropy of the samples varies between $6.4 \%$ and $-20.0 \%$ (Table 1 ).

The fine-grained sediments of the bioturbated mud and distal levee deposits, like those of the proximal levee deposits, are characterized by very open fabrics in high porosity, near-surface samples, and distinctly more closed, compacted fabrics in deeper lower porosity sediments. At 2.65 mbsf, Sample 155-935A-1H-2, 115-117 cm, is typical of the shallow bioturbated sediments. It exhibits a highly porous fabric with large voids (up to $10 \mu \mathrm{m}$ ) and small, flocculated domains with few clay particles (Fig. 8). The clay domains consist of face-to-face books, stepped face-to-face books, and small, randomly arranged chains. Silt grains are loosely packed with a weak preferred orientation. Sample 155-930B-11H-4, 26-28 cm, from $95.96 \mathrm{mbsf}$, is characterized by larger domains and a marked reduction in visible porosity in the SE image (Fig. 9). The porosity of this sample, 50\%, is low for its burial depth (Table 1). The low porosity is reflected in a tighter packing of silt particles and more grain-to-grain contacts. Silt-sized mica is abundant in Sample 155-930B-11H-4, 26-28 cm, and the BSE image displays a distinct preferred orientation (Fig. 9). The porosity of Sample 155-938A-22X-3, 100-102 cm, 50\%, is more typical for its burial depth of 200.50 mbsf. This sample has a dense fabric with limited visible porosity and individual domains (Fig. 10). The compacted domains are arranged in a well-developed 


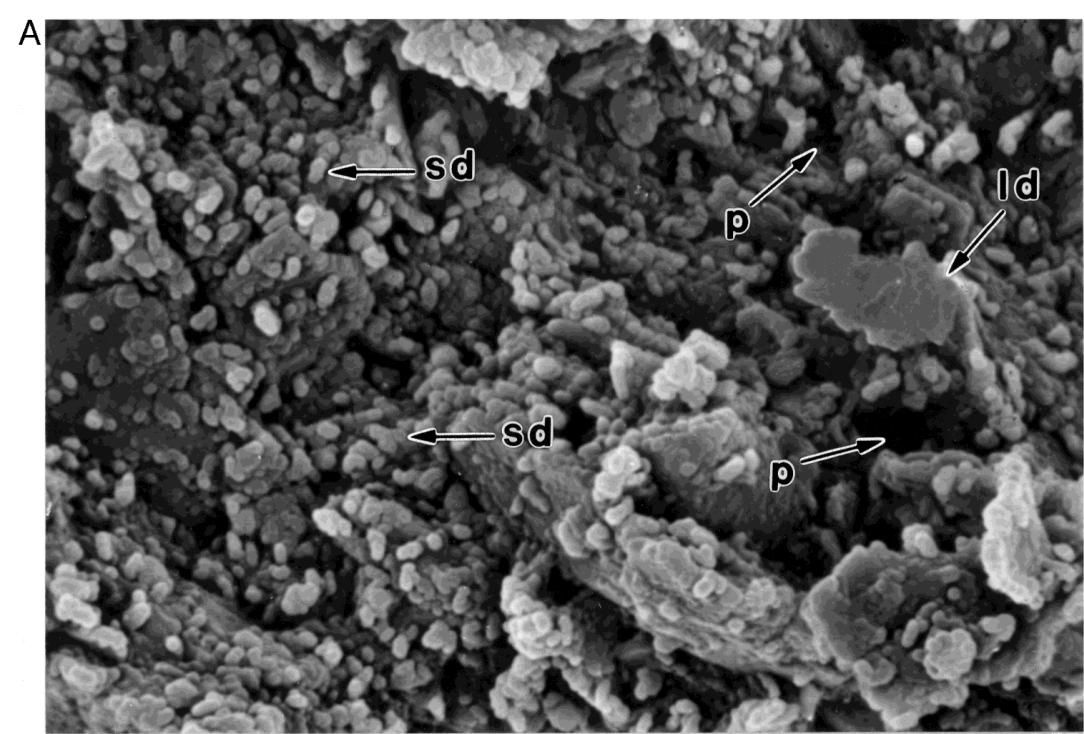

$10 \mu \mathrm{m}$

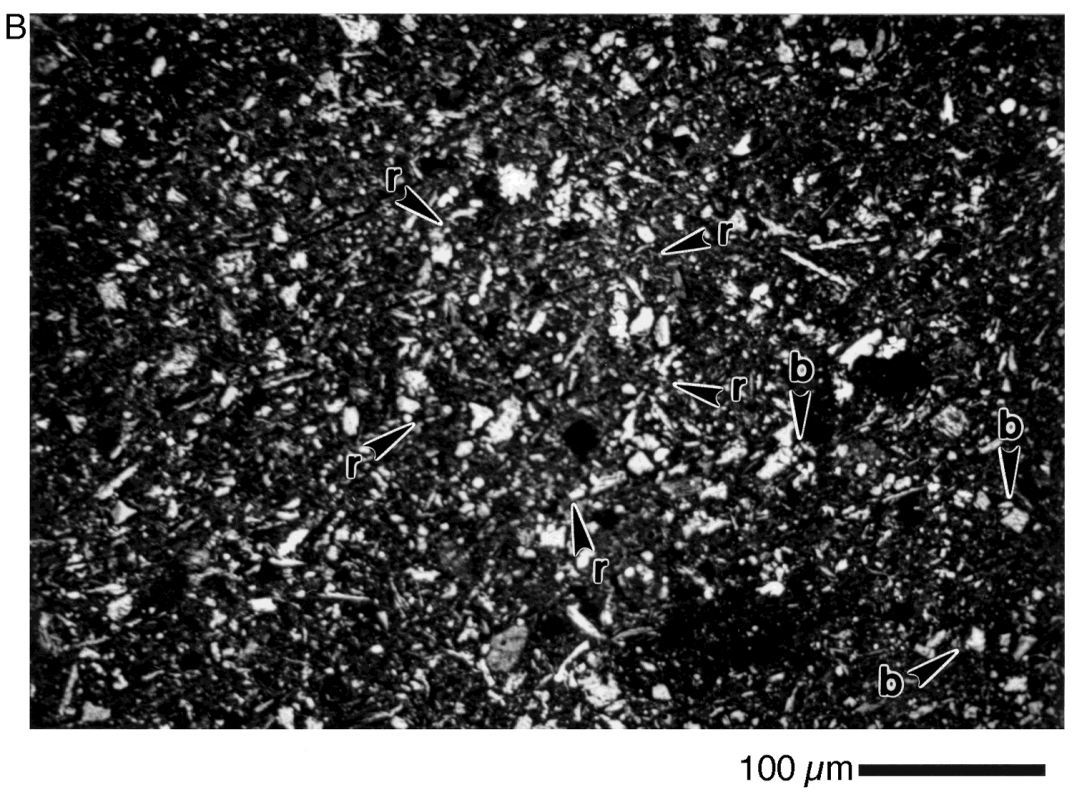

C

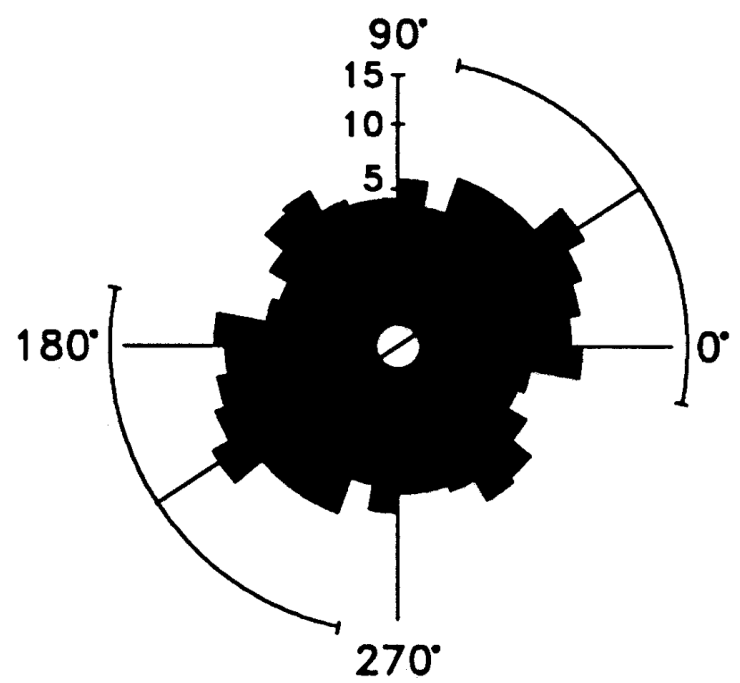

Figure 4. Sample 155-935A-4H-3, 77-80 cm; proximal levee; 26.27 mbsf. A. SE micrograph, open fabric with small (sd) and large (ld) clay domains and large open pores (p). In this and all other micrographs, the images represent sections cut perpendicular to bedding. Bedding is aligned to be approximately horizontal in the figures. B. BSE micrograph, large pores and silt grains with variable orientations. Backscattered images of polished sections primarily reflect differences in atomic number. Impregnating resin, which fills open pores, has a low atomic number and is black, whereas silt particles have a higher atomic number and are light gray to white. Clays have an intermediate number and appear a diffuse gray. Features in the arrangement of the silt grains include a ring (r), 100-150 $\mu \mathrm{m}$ in diameter, and two bands of silt grains (b) that are $\sim 1$ grain thick and cut diagonally across the image. C. Rose diagram for silt particle orientation in BSE micrograph. This and subsequent diagrams are equal-area roses in which the radius is proportional to the square root of the percentage of observations in $10^{\circ}$-wide classes. The scale for the classes, in percent, is indicated on the $90^{\circ}$ axis. The $0^{\circ}-$ $180^{\circ}$ axis is the horizontal. The mean orientation vector is indicated by the line drawn through the data, and $95 \%$ confidence intervals bracket the mean. For Sample 155$935 \mathrm{~A}-4 \mathrm{H}-3,77-80 \mathrm{~cm}$, the circular variance $\left(s^{2}\right)=0.89$, and the average major axis length $\left(\bar{d}_{\max }\right)=15.0 \mu \mathrm{m}$. 
Figure 5. Sample 155-938A-11X-2, 55-57 cm; proximal levee; 95.15 mbsf. SE micrograph, dense fabric with large domains (d), small pores, and a roughly parallel particle alignment.

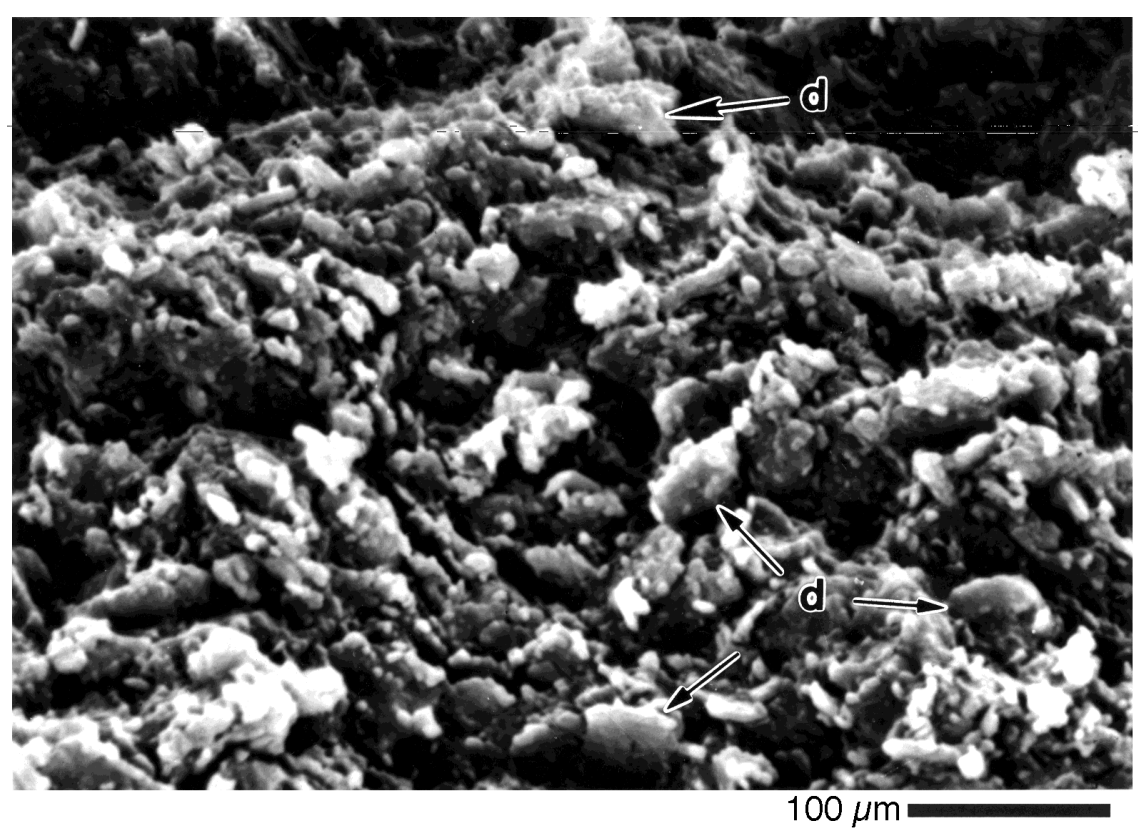

parallel orientation. Sampling-related fractures are present in the sample and parallel the clay domains (Fig. 10). Sample 155-935A$31 \mathrm{X}-5,67-69 \mathrm{~cm}$, is the most deeply buried sediment examined from the group of samples deposited distant from active channels. It has a porosity of $47 \%$ at a burial depth of 282.34 . The fabric of this sample is dense with low visible porosity and compacted clay domains with a well-defined parallel arrangement (Fig. 11).

Particle orientation data are only available for Samples 155935A-1H-2, 115-117 cm, and 155-930B-11H-4, 26-28 cm. Sample 155-935A-1H-2, 115-117 cm, displays a horizontal mean direction of alignment and the lowest variance measured for near-surface sediments, $s^{2}=0.73$. The mica-rich sediments of Sample 155-930B$11 \mathrm{H}-4,26-28 \mathrm{~cm}$, display the strongest preferred orientation of all of the sediments for which particle orientation data were obtained. The mean direction of the orientation vector is $150^{\circ}$, and $s^{2}=0.61$.

\section{Mass-Transport Deposits}

Fine-grained sediments were sampled from three MTDs, the surficial Western Debris Flow, the buried Unit R, and the buried unnamed MTD at Site 930. The depth range of these samples is 8.85$240.70 \mathrm{mbsf}$, and porosity ranges from 60\% (Sample 155-941B-2H$2,75-77 \mathrm{~cm}$ ) to $36 \%$ (Sample 155-930B-24X-3, 27-29 cm). The range in resistivity anisotropy of the fine-grained mass-transport fabric samples is large, with values between $-19.1 \%$ and $7.2 \%$ (Table 1 ).

The three samples from Hole 941B display an irregular downhole variation in porosity. Sample 155-941B-2H-2, 75-77 cm, from 8.85 mbsf, has a porosity of $60 \%$ and is characterized by an open, porous fabric and small, flocculated domains consisting of a few clay particles (Fig. 12). Silt grains in this sample are larger $\left(\bar{d}_{\max }=15.6 \mu \mathrm{m}\right)$ than those of the other two samples from Hole 941B, and they are randomly arranged and floating in a clay matrix (Fig. 12). At 56.83 mbsf, the porosity of Sample 155-941B-7H-5, 123-125 cm, 48\%, is unusually low. Reduced visible porosity and more compacted clay domains characterize the SE image of this sediment (Fig. 13). The BSE image of Sample 155-941B-7H-5, 123-125 cm, shows randomly arranged fine silt $\left(\bar{d}_{\max }=7.3 \mu \mathrm{m}\right)$ floating in a clay matrix (Fig. 13). Elongate grains in this sample exhibit a slight preferred subhorizontal alignment. The porosity of Sample 155-941B-11H-5, 86-88 $\mathrm{cm}, 50 \%$, is more typical for its burial depth (Fig. 3). A decrease in visible porosity, an increase in domain size, and an increase in clay particles per domain give the sediment a dense fabric (Fig. 14). As in the other Western Debris Flow samples, silt grains appear to be floating in a clay matrix; however, in Sample 155-941B-11H-5, 86-88 $\mathrm{cm}$, there is a rough alignment of silt grains that with a mean orientation of $131^{\circ}$.

Much lower porosity characterizes the fabric samples from the buried MTDs. Fine-grained sediments from Unit R at $220.56 \mathrm{mbsf}$ in Hole 935A (Sample 155-935A-25X-2, 46-49 cm) are characterized by a porosity of $45 \%$ and a dense fabric (Fig. 15). The overall topography in the SE image reflects a crude, nearly horizontal layering. Silt particles are more closely spaced in Sample 155-935A-25X-2, 46-49 $\mathrm{cm}$, than in the samples from the Western Debris Flow, and a subhorizontal alignment is present (Fig. 15). The fabric sample from 218.97 mbsf in the unnamed MTD at Site 930 (Sample 155-930B$24 \mathrm{X}-3,27-29 \mathrm{~cm}$ ) is in an interval described as a displaced block. The unusually low porosity of this sediment, $36 \%$, is consistent with the interpretation of a displaced, formerly more deeply buried sediment mass. The fabric of this sediment is dense, and individual clay domains cannot be distinguished (Fig. 16). The BSE image displays closely packed silt grains arranged in crude bands of coarse and fine silt that cut across the sample at a low angle (Fig. 16).

Particle orientation data for the fine-grained mass-transport sediments contain a mixture of patterns. The highly variable particle orientations for Samples 155-941B-2H-2, 75-77 cm, and 155-941B$7 \mathrm{H}-5,123-125 \mathrm{~cm}\left(s^{2}=0.91\right.$ and 0.88 , respectively), typify randomly oriented clasts in debris-flow deposits. It is worth noting that the fabric of these two samples is similar despite the significant difference in the long axis length of their silt grains. A higher degree of particle alignment is displayed in Samples 155-941B-11H-5, 86-88 cm, 155-935A-25X-2, 46-49 cm, and 155-930B-24X-3, 27-29 cm, for which the circular variances are $0.74,0.62$, and 0.75 , respectively. The mean orientation direction of $131^{\circ}$ in Sample 155-941B-11H-5, $86-88 \mathrm{~cm}$, roughly matches the $75^{\circ}$ dip of color banding described for this interval in Hole 941B (Flood, Piper, Klaus, et al., 1995). The inclined, crude layers of alternating coarse and fine silt in Sample 155-930B-24X-3, 27-29 cm, are from an interval described as containing tilted blocks of plastically deformed sediment. 

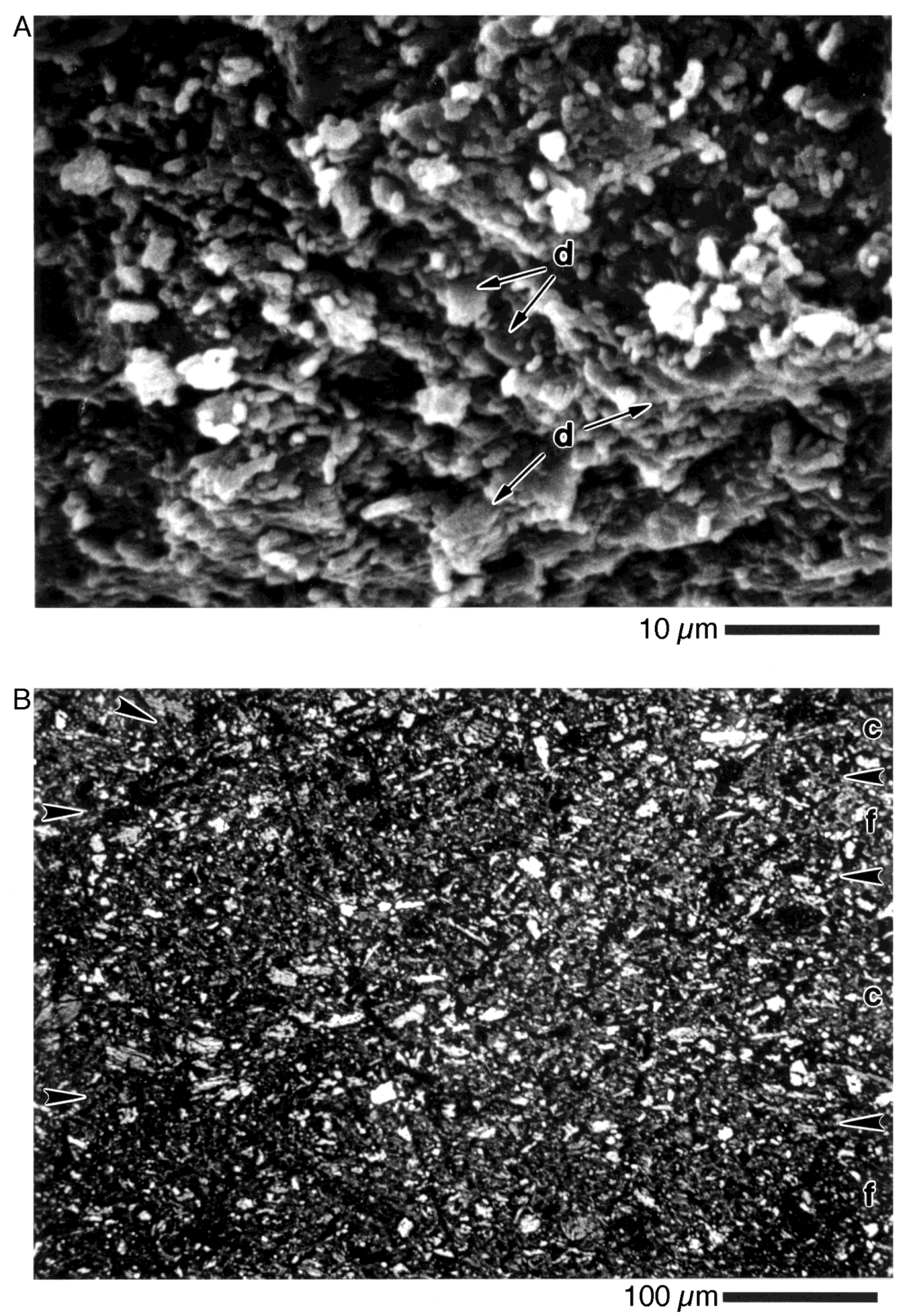

C

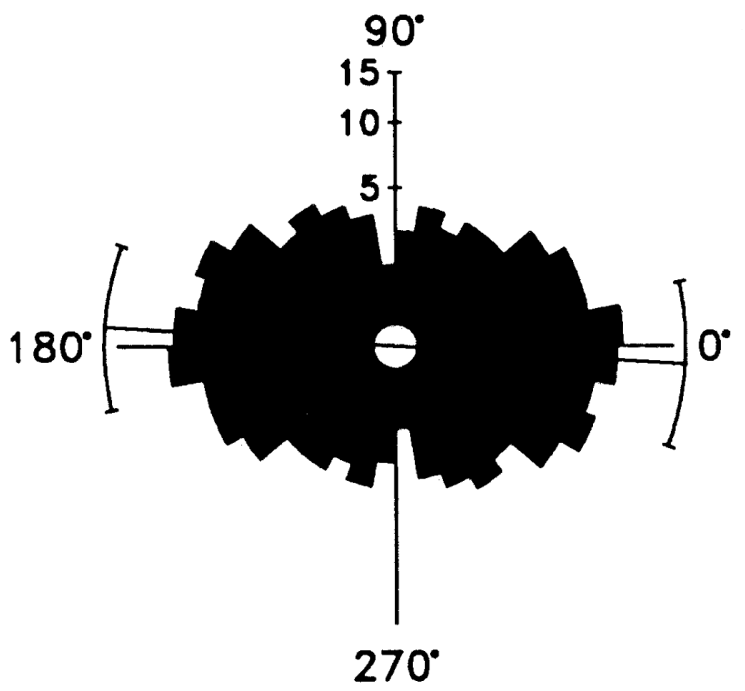

Figure 6. Sample 155-933A-20X-3, 83-85 cm; proximal levee; 180.73 mbsf. A. SE micrograph, compact domains (d) and a prevailing, nearly horizontal particle alignment. B. BSE micrograph, rough zonation of coarse (c) and fine (f) silt. C. Rose diagram for silt particle orientation in BSE micrograph. $s^{2}=0.69$; $\bar{d}_{\max }=11.7 \mu \mathrm{m}$. 

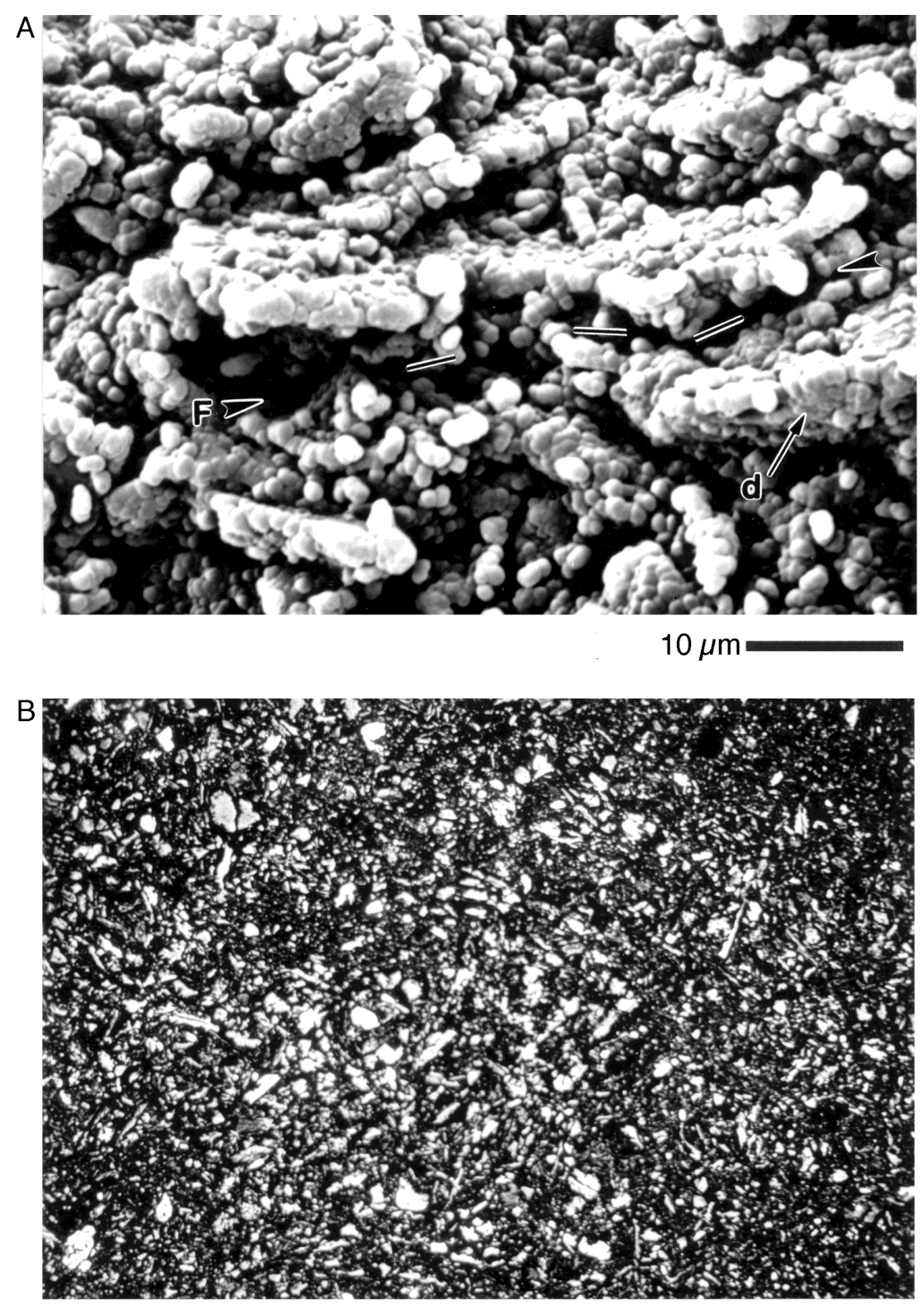

C

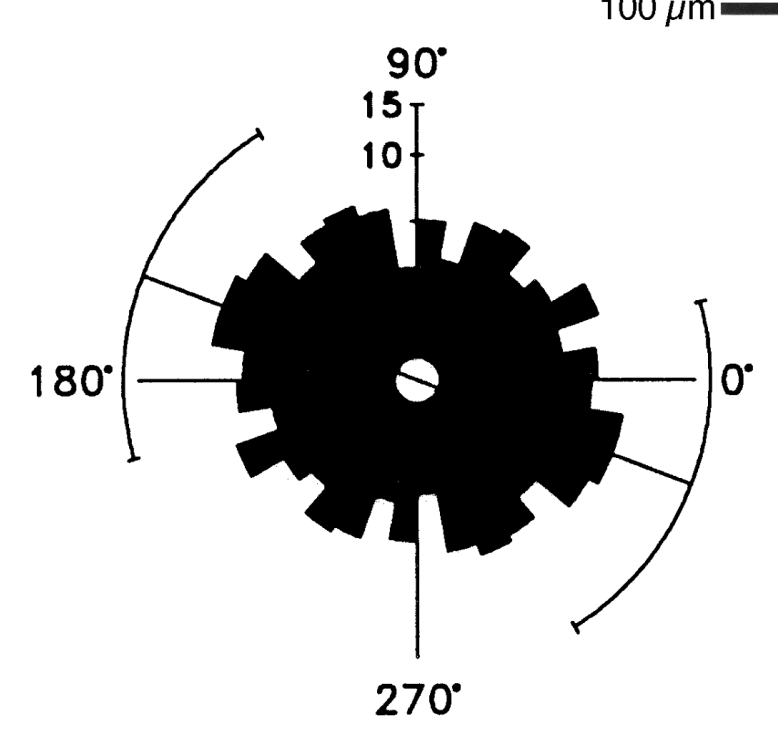

Figure 7. Sample 155-935A-40X-4, 29-31 cm; proximal levee; 367.79 mbsf. A. SE micrograph, dense fabric with compacted domains (d) and little visible porosity. Bedding displays a crude parallel alignment accentuated by fractures (F). B. BSE micrograph, closely spaced silt particles with variable orientations. C. Rose diagram for silt particle orientation in BSE micrograph. $s^{2}=0.86 ; \bar{d}_{\max }$ 


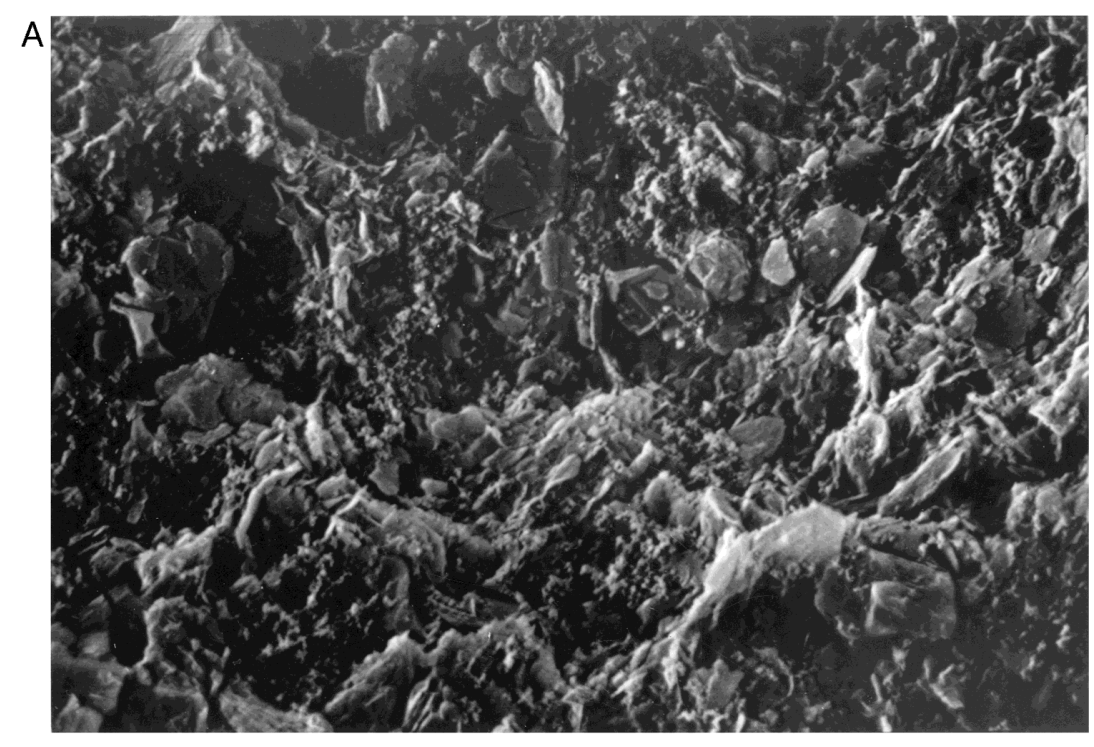

$10 \mu \mathrm{m}$

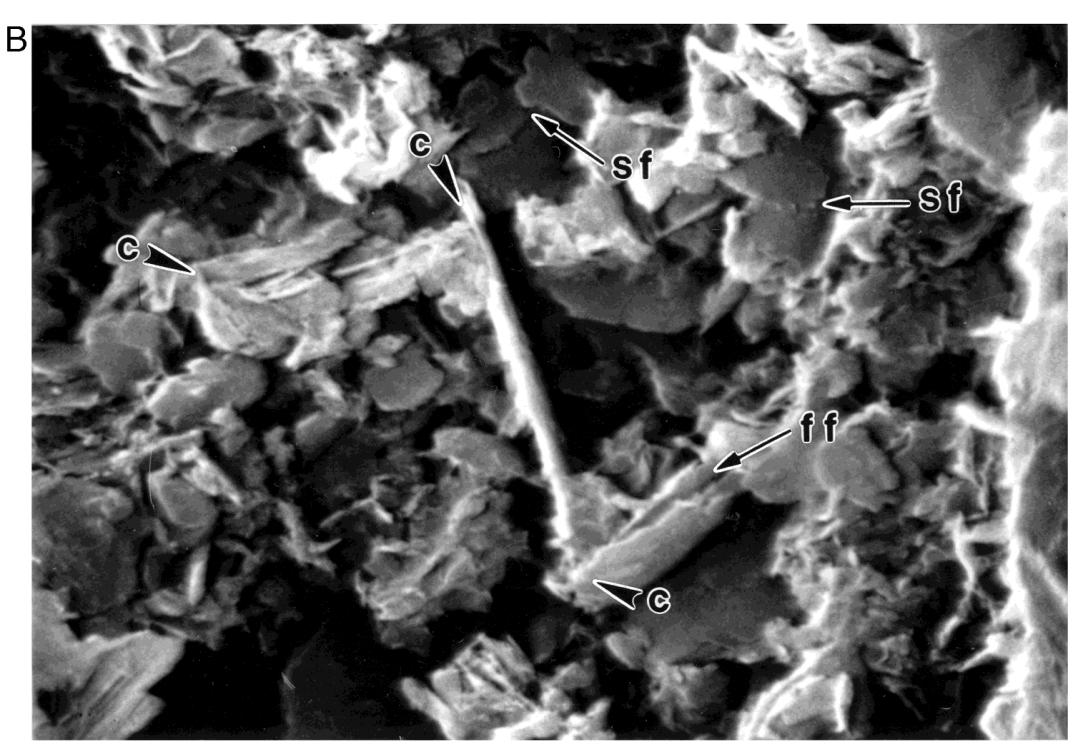

$10 \mu \mathrm{m}$

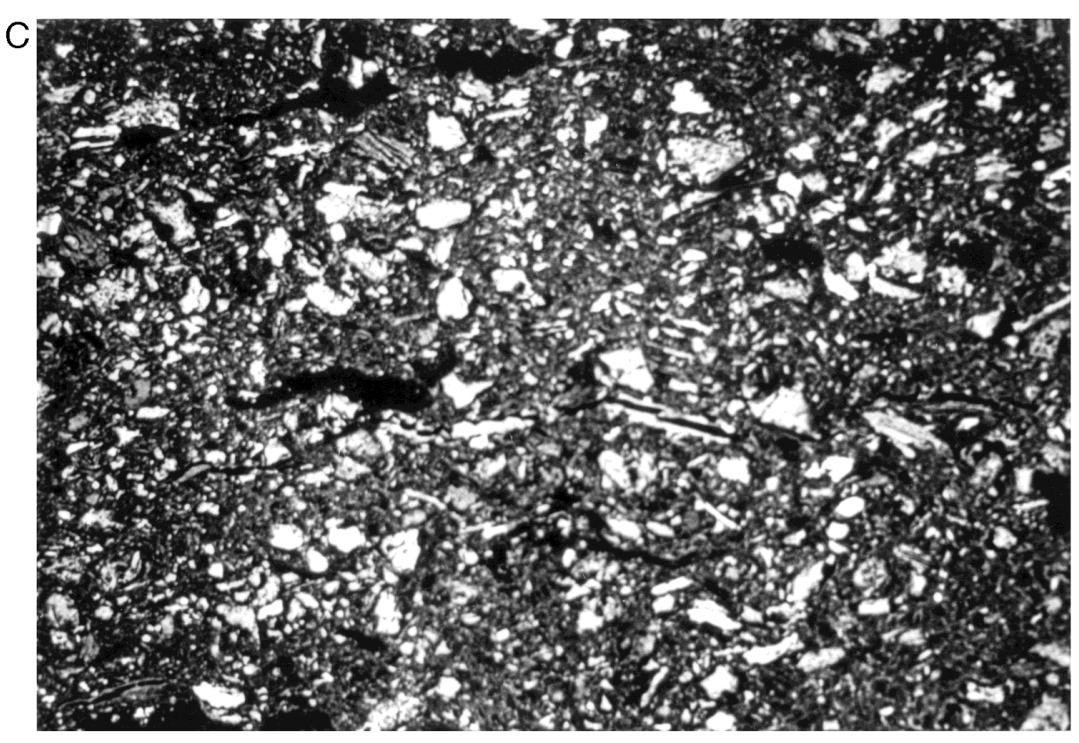

$100 \mu \mathrm{m}=$

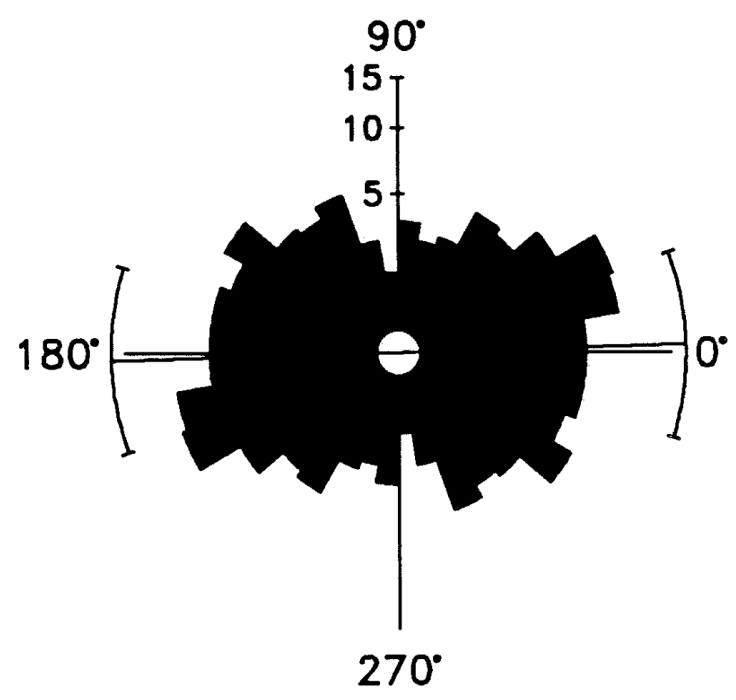

Figure 8. Sample 155-935A-1H-2, 115-117 cm; bioturbated mud; 2.65 mbsf. A. SE micrograph, open fabric with small clay domains. The overall sample fabric displays a crude horizontal orientation. B. SE micrograph, large pores and small clay domains with face-to-face (ff) and stepped face-to-face (sf) books, and small, randomly arranged chains (linked domains highlighted by arrows 
Figure 9. Sample 155-930B-11H-4, 26-28 cm; distal levee; 95.96 mbsf. A. SE micrograph, large clay domains (d), silt particles (s), and low visible porosity. Feature $\mathrm{F}$ is a fracture that opened during sample preparation. B. BSE micrograph, more tightly packed silt particles with grain-to-grain contacts. Abundant mica grains (m) contribute to a moderately strong, subhorizontal, preferred orientation. C. Rose diagram for silt particle orientation in BSE micrograph. $s^{2}=0.61 ; \bar{d}_{\text {max }}$ $=16.9 \mu \mathrm{m}$.
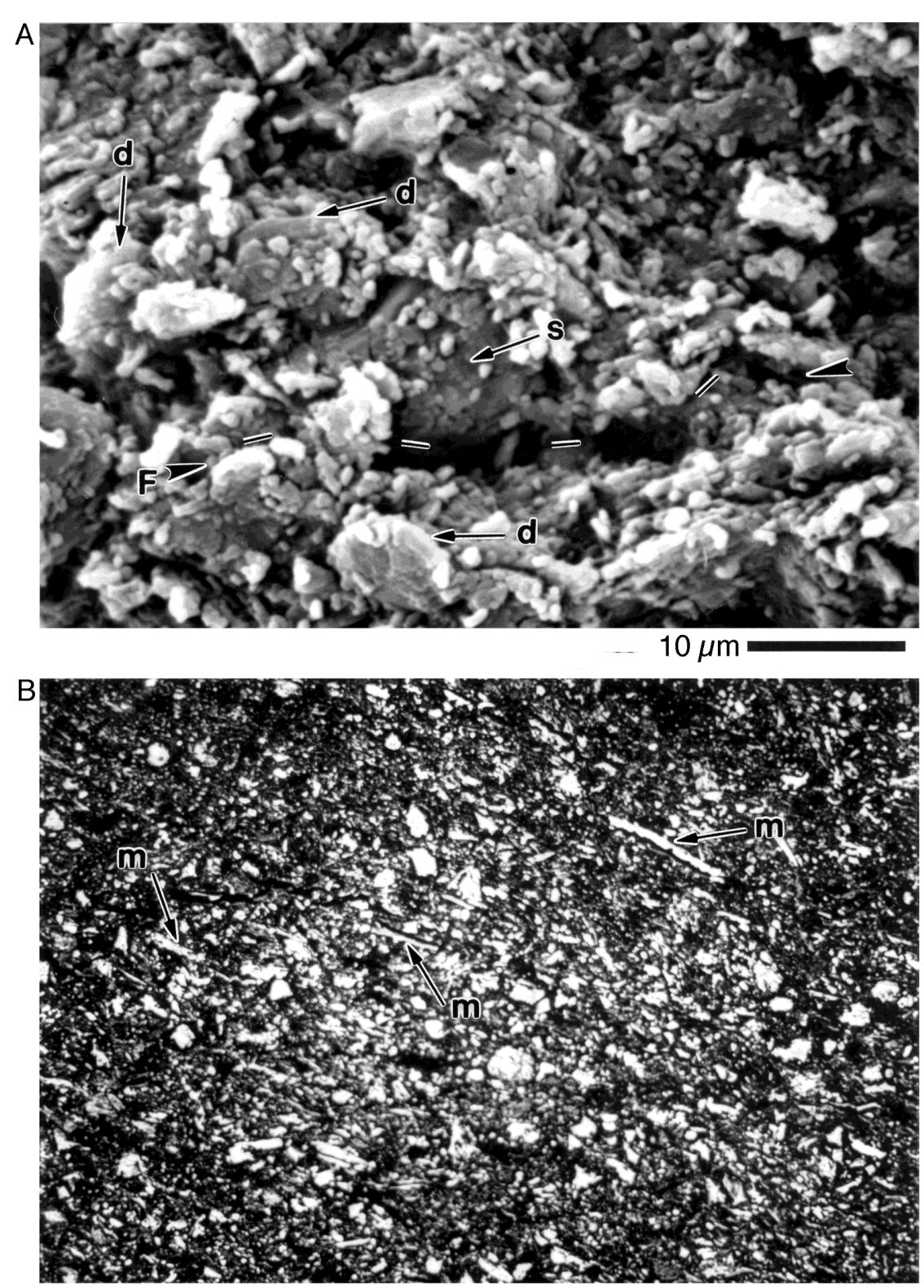

C

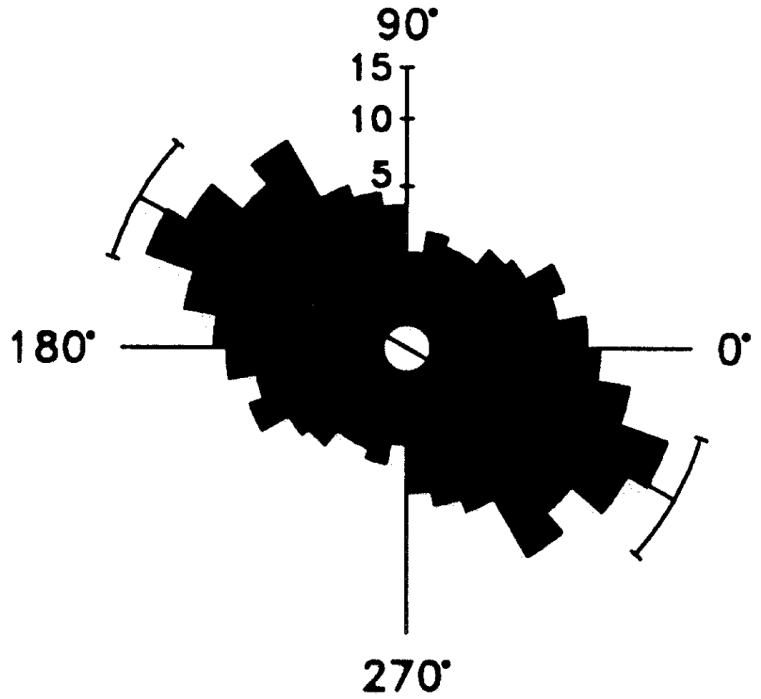




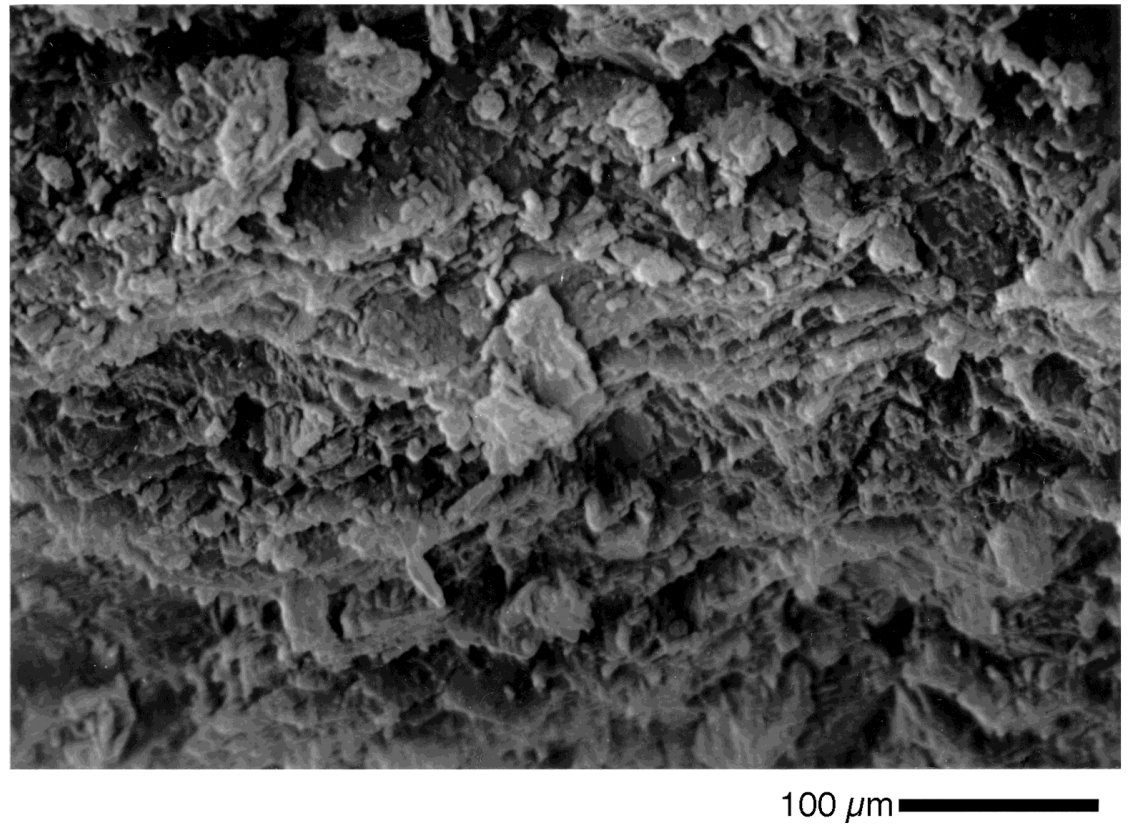

Figure 10. Sample 155-938A-22X-3, 100-102 cm; distal levee; 200.50 mbsf. SE micrograph, dense fabric, porosity, and individual domains are difficult to distinguish. The sediment displays a strong preferred orientation, with fractures parallel to bedding and the compacted domains.

\section{DISCUSSION}

\section{Influence of Depositional Process on Sediment Fabric}

The fabrics of fine-grained sediments of proximal levee, bioturbated mud and distal levee, and MTDs on the Amazon Fan display attributes that differ among the sediment groups. The differences in the fabrics are not so striking as to uniquely characterize a given facies; however, there are differences that are consistent with the sediment origins. The fabric variations in part reflect differences in the processes of deposition, but they are also the product of other factors such as variation in composition and postdepositional modification.

Differences in the fabric of fine-grained proximal levee, bioturbated mud and distal levee, and mass-transport sediments can be characterized by the variations in particle orientations. Sediments deposited by pelagic settling, or by turbidity currents distant from active channels, show the best development of preferred particle alignment that is horizontal or at a low angle to bedding. Sample 155-935A-1H$2,115-117 \mathrm{~cm}$, is characterized by silt grains that are aligned horizontally with a variance that is the lowest of the near-surface samples (Fig. 8). The preferred particle orientation in this bioturbated mud may seem unusual, but randomized, bioturbated fabrics and primary fabrics with preferred orientation can coexist in close proximity (O'Brien, 1987). Sample 155-930B-11H-4, 26-28 cm, a distal levee sediment buried at $95.96 \mathrm{mbsf}$, displays a silt alignment that is subhorizontal (Fig. 9), but it has the lowest circular variance of all the samples for which orientation data are available. Silt grain orientation was not measured for the deeper distal levee sediments; however, Figures 10 and 11 show that samples from 200 and $280 \mathrm{mbsf}$ (Samples 155-938A-22X-3, 100-102 cm, and 155-935A-31X-5, 67$69 \mathrm{~cm}$, respectively) are characterized by a clear fabric alignment parallel to bedding. In contrast, the fine-grained proximal levee sediments are characterized by more variable particle orientations at shallow burial depth (Fig. 4). Fabric alignment is less variable and more nearly horizontal at $180 \mathrm{mbsf}$ (Fig. 6), but the variance of the silt orientation is greater than that of the distal levee sample from 96 mbsf. The increased variability of silt grain orientations in the deep proximal levee sample (Sample 155-935A-40X-4, 29-31 cm; Fig. 7) does not fit the general hypothesis that reorientation of particles during compaction yields a more nearly horizontal and less variable fabric alignment. Core $155-935 \mathrm{~A}-40 \mathrm{X}$ is moderately bioturbated, and the variable particle orientations suggest that compaction has not significantly realigned a fabric originally disrupted by bioturbation. A similar lack of reorientation in buried bioturbated fine-grained sediments has been described by O'Brien (1987).

The differences between the fabrics of the bioturbated mud and distal levee deposits and the proximal levee deposits are consistent with observations of previous workers. O'Brien et al. (1980) examined the fabrics of fine-grained hemipelagic and turbidity current deposits and concluded that the turbidites were characterized by random particle arrangements and that the hemipelagic sediments exhibited a higher degree of preferred orientation. They attributed the contrasting fabrics to differences in sedimentation rate, with the random fabric of the turbidites resulting from rapid sedimentation and the better aligned fabric of the hemipelagic sediments resulting from lower sedimentation rates. Shepard and Rutledge (1991) observed less pronounced differences in the fabrics of hemipelagic clays and turbidites and attributed these differences to variation in particle type and not particle orientation. The proximal levee deposits were deposited more rapidly than the sediments located farther from active channels. Compaction corrected sedimentation rates, based on age models of Flood, Piper, Klaus, et al. (1995), range from 15 to $100 \mathrm{~m} / \mathrm{k} . \mathrm{y}$. for the proximal levee samples and from 0.5 to $30 \mathrm{~m} / \mathrm{k}$.y. for the bioturbated mud and distal levee sediments examined. In light of these differences, the more variable orientations of particles in the proximal levee deposits might reflect, in part, the influence of more rapid sedimentation. The importance of differences in particle type, however, cannot be overlooked. Mica grains are clearly more abundant in Sample 155-930B-11H-4, 26-28 cm (Fig. 5.), than in the other samples, and this greater abundance of platy, more easily aligned grains is accompanied by the lowest variance in particle orientations. Variability in silt size does not appear to affect the fabric alignment. In the bioturbated mud, distal levee, proximal levee, and MTDs, there is not a relationship between the long axis length of the grains and grain orientation.

The fine-grained sediments of the MTDs exhibit fabrics that differ from the those of the proximal levee, bioturbated mud, and distal levee deposits. The fabrics are consistent with the means by which these deposits were emplaced. The highly variable orientations of silt particles floating in a clay matrix, displayed by Samples 155-941B2H-2, 75-77 cm (Fig. 12), and 155-941B-7H-5, 123-125 cm (Fig. 13), from the Western Debris Flow, typify the random clast fabric 
Figure 11. Sample 155-935A-31X-5, 67-69 cm; calcareous clay; $282.34 \mathrm{mbsf}$. SE micrograph, dense fabric with low visible porosity and compacted domains with a preferred, bedding-parallel arrangement.

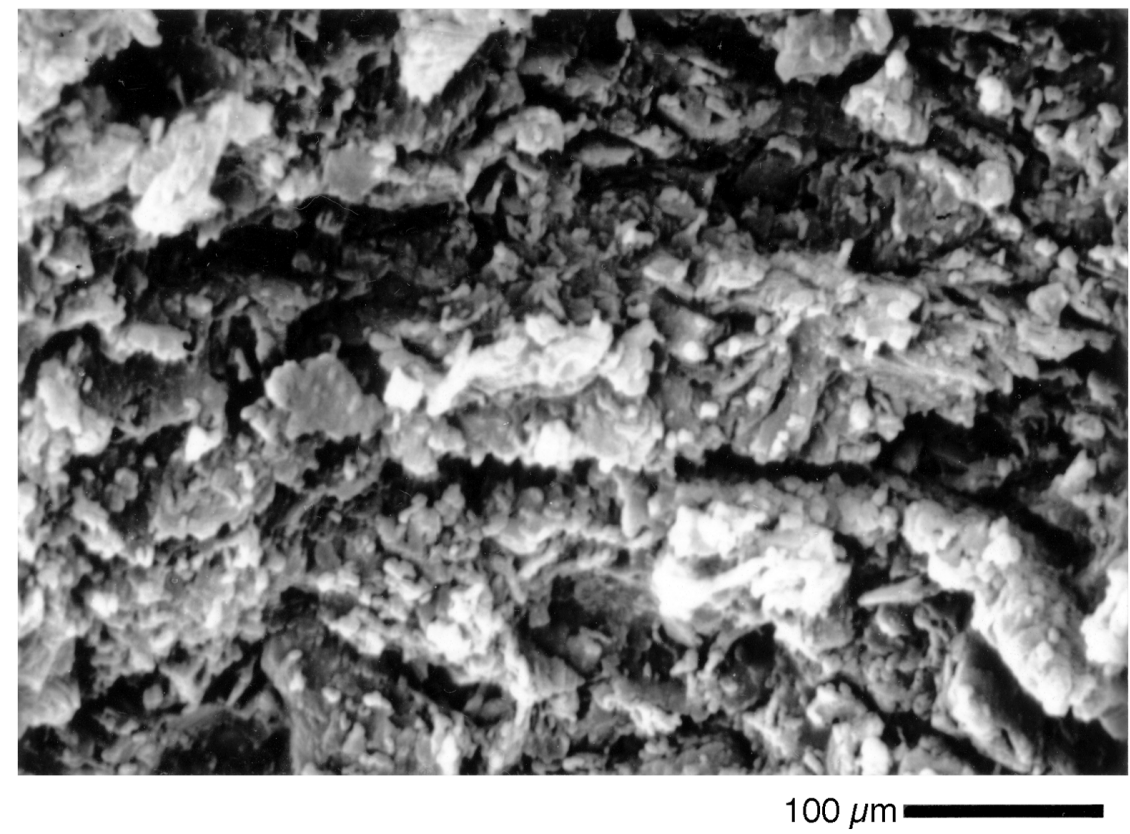

commonly attributed to debris flows. Dipping color bands and laminae are ubiquitous in sediments recovered from the Western Debris Flow and display varying degrees of deformation. The orientation of the silt fabric in Sample 155-941B-11H-5, 86-88 cm (Fig. 14), agrees with the orientation of the macroscopic banding of Core 155$941 \mathrm{~B}-11 \mathrm{H}$. It is uncertain whether the silt alignment reflects a primary lamination or a product of deformation. Consequences of deformation may be evident in Sample 155-930B-24X-3, 27-29 cm (Fig. 16), which is from that part of Hole 930B that is interpreted to have penetrated a sediment block displaced from higher on the continental slope (Flood, Piper, Klaus, et al., 1995). Plastically deformed bedding and evidence of shearing is common in cores from this block. One of the microfabric features that has been described as a byproduct sediment shearing is a textural segregation of particles (Torresan and Schwab, 1987). The crudely alternating fine and coarse silt intervals displayed in the BSE image (Fig. 16) of Sample 155-930B-24X$3,27-29 \mathrm{~cm}$, may be such a product of shearing. Other possible evidence of shearing includes the manner in which samples from Site 930 fractured during mounting on SEM stubs and small, nearly smooth planes suggestive of slickensides in SE images.

During Leg 155, the anisotropy of electrical resistivity was observed to have a general relationship with sediment lithology. Wellbedded levee sequences were characterized by more negative anisotropy values, suggesting a preferred fabric orientation parallel to bedding, and MTDs were characterized as being isotropic, or possessing widely varying anisotropy (Flood, Piper, Klaus, et al., 1995). Qualitatively, a higher degree of preferred orientation was more commonly observed in SE and BSE images of proximal and distal levee sediments than in images of sediments from the MTDs. The quantitative orientation data provide little support for the original interpretation of the resistivity anisotropy trends. Comparing the anisotropy values listed in Table 1 with the orientation data accompanying the SEM images, it can be seen that there is not a match between negative anisotropy and fabrics with a dominant horizontal alignment. The high variability of the anisotropy data in Table 1 probably contributes to the poor correlation. The lack of agreement between the resistivity anisotropy and the BSE orientation measurements may also reflect differences in the sediment fractions that influence these parameters. The BSE image measurements are based on silt particle orientation, and the variation in electrical resistivity is more likely controlled by clay particle orientation.

\section{Burial Transformation of Sediment Fabric}

Most changes in fabric that accompany the burial of fine-grained sediments on the Amazon Fan occur in the uppermost part of the sediment column. The open fabrics with large pores and small domains, consisting of few clay particles, are restricted to those samples from less than 30 mbsf. Below this depth, in all of the sediment groups, proximal levee, bioturbated mud and distal levee, and mass transport, the open structure collapses, yielding a more dense fabric. The fabrics of samples from 80 to $100 \mathrm{mbsf}$ are dense with larger, more compacted domains and little visible porosity. In BSE images, this change is typically reflected by an increasingly tighter packing of the silt grains. Below $80 \mathrm{mbsf}$, the rate of fabric change with depth is significantly reduced. With increasing burial, the growth of domains and reduction in the distance between silt particles make it increasingly difficult to distinguish the clay domains. The pattern of fabric transformation, with large changes in the upper part of the sediment column and decreasing rate of change with increasing burial, roughly mirrors the change in bulk porosity which decreases rapidly in the upper $50 \mathrm{~m}$ of the sediment column and changes much more slowly below 100 mbsf (Figs. 2, 3).

The collapse of the open fabric of clay-rich sediments with oblique particle orientations has been shown to result in a progressive rearrangement of clay particles to a more nearly horizontal alignment with increasing burial depth (Bennett et al., 1977, 1981; Callaway and Busch, 1991). The high silt content of Amazon Fan sediments makes them somewhat different, but intuitively, it would be expected that they would take on an increasingly preferred horizontal alignment with increasing burial. Development of a higher degree of nearly horizontal preferred orientation is best demonstrated by the bioturbated muds and distal levee sediments, and to a lesser extent by proximal levee deposits. Orientation trends with depth are more problematic in the fine-grained sediments of the MTDs as a result of the deformation and presence of displaced blocks in these deposits.

An additional consequence of the collapse of the open fabric of the near-surface sediments is the loss of some of the fine fabric details that occur in the shallow sediments. The diffuse ring of silt particles in Sample 155-935A-4H-3, 77-80 cm (Fig. 4), and similar features in Sample 155-930B-2H-4, 79-82 cm (not shown), resemble structures identified as meniscate backfill structures in bioturbated mud (Reynolds and Gorsline, 1991). This type of structure was only ob- 
served in the sediments from less than $30 \mathrm{mbsf}$, and is apparently destroyed with the particle reorientation that accompanies increasing burial.

Time-dependent compaction processes and "aging" effects can be expressed as variations in sediment fabric. However, the range in ages spanned by the Amazon Fan sediments is not so great as to result in noticeable differences in fabric. Sample 155-933A-20X-3, 83-85 $\mathrm{cm}$, from the Bottom Levee Complex, is middle Pleistocene in age and the oldest sediment that was examined. The bulk properties and fabric (Fig. 6) of this sediment are not unusual or different than the properties and fabric of much younger sediments from about the same burial depth, at Site 938 (Fig. 10).

A burial-related problem difficult to resolve is the high pore pressure present in levee deposits underlying MTDs. The dense fabric of displaced blocks, such as that of Sample 155-930B-24X-3, 27-29 cm (Fig. 16), probably would be an impermeable barrier, but it is unlikely that such a block would have the lateral extent to impede the drainage of underlying sediments. Broad coverage of an area with sediment of the fine grain size and random fabric possessed by Sample 155-941B-7H-5, 123-125 cm (Fig. 13), may be an effective impediment to the drainage of underlying sediments, but the variability displayed in the fabrics of the mass-transport sediments makes such a hypothesis highly speculative.

\section{CONCLUSIONS}

1. Fine-grained bioturbated mud and distal levee sediments display the highest degree of preferred orientation and the best developed trend of particle reorientation to a more nearly horizontal alignment with increasing burial depth. The more variable particle orientations of the proximal levee deposits most likely reflect the more rapid deposition of these sediments. Differences in composition of silt particles, such as a greater abundance of platy minerals, may also affect the development of a preferred particle orientation.

2. MTDs are characterized by randomly oriented silt grains in a clay matrix and fabrics that reflect the larger scale sediment deformation. The fabric of the fine-grained sediments of the MTDs displays the influence of various scales of folds, shear zones, and displaced blocks. As a result of features such as these, consistent downhole changes in fabric were not observed for the MTDs. The variability of fabric styles also makes it difficult to identify why the MTDs commonly act as a barrier to the drainage of underlying levee deposits.

3. The association between negative resistivity anisotropy and well-bedded levee sequences and variable anisotropy and MTDs can not be confirmed by fabric observations. The proximal levee and distal levee sediments appear to show a greater degree of preferred orientation than the MTDs; however, these observations are not supported by quantitative orientation data.

4. The greatest fabric change in the fine-grained Amazon Fan sediments is the collapse of the porous, open structure that characterizes sediments from less than 30-m burial depth. With increasing burial, the rate of fabric change with depth decreases dramatically. The downhole reduction in bulk porosity matches the rate of fabric change with depth.

\section{ACKNOWLEDGMENTS}

We thank Dave Long, Pat Manley, and Wonn Soh for helping collect the fabric samples and physical properties data during Leg 155. We thank Kim McLean for assistance in preparing the SEM samples and greatly appreciate the many hours that Al Falster provided operating the SEM and offering advice at various stages of the project.
Critical reviews by Gideon Almagor and Neal O'Brien improved the manuscript. This research was completed with funds provided by the U.S. Science Support Program associated with the Ocean Drilling Program, which is sponsored by the National Science Foundation and the Joint Oceanographic Institutions, Inc. Conclusions expressed in this publication are those of the authors and do not necessarily reflect the views of the National Science Foundation, the Joint Oceanographic Institutions, Inc., Texas A\&M University, or the Texas A\&M Research Foundation.

\section{REFERENCES}

Bennett, R.H., Bryant, W.R., and Hulbert, M.H. (Eds.), 1991a. Microstructure of Fine-Grained Sediments: From Mud to Shale: New York (Springer-Verlag).

Bennett, R.H., Bryant, W.R., and Keller, G.H., 1977. Clay fabric and geotechnical properties of selected submarine sediment cores from the Mississippi Delta. NOAA Prof. Pap., 9.

, 1981. Clay fabric of selected submarine sediments: fundamental properties and models. J. Sediment. Petrol., 51:217-232.

Bennett, R.H., and Hulbert, M.H., 1986. Clay Microstructure: Boston (IHRDC Publ.).

Bennett, R.H., O'Brien, N.R., and Hulbert, M.H., 1991b. Determinants of clay and shale microfabric signatures: processes and mechanisms. In Bennett, R.H., Bryant, W.R., and Hulbert, M.H. (Eds.), Microstructure of Fine-Grained Sediments: From Mud to Shale: New York (Springer-Verlag), 5-32.

Callaway, J.S., and Busch, W.H., 1991. Burial transformation of sediment fabric at Ocean Drilling Program sites in the western Arabian Sea. In Prell, W.L., Niitsuma, N., et al., Proc. ODP, Sci. Results, 117: College Station, TX (Ocean Drilling Program), 221-238.

Damuth, J.E., Flood, R.D., Knowsmann, R.O., Belderson, R.H., Gorini, M.A., 1988. Anatomy and growth patterns of Amazon deep-sea fan as revealed by long-range side-scan sonar (GLORIA) and high-resolution seismic studies. AAPG Bull., 72:885:911.

Flood, R.D., Piper, D.J.W., Klaus, A., et al., 1995. Proc. ODP, Init. Repts., 155: College Station, TX (Ocean Drilling Program).

Flood, R.D., Piper, D.J.W., and Shipboard Scientific Party, 1995. Introduction. In Flood, R.D., Piper, D.J.W., Klaus, A., et al., Proc. ODP, Init. Repts., 155: College Station, TX (Ocean Drilling Program), 5-16.

Hulbert, M.H., and Bennett, R.H., 1975. Electrostatic cleaning technique for fabric SEM samples. Clays Clay Miner., 23:331.

Manley, P.L., and Flood, R.D., 1988. Cyclic sediment deposition within the Amazon deep-sea fan. AAPG Bull., 72:912-925.

Mitchell, J.K., 1976. Fundamentals of Soil Behavior: New York (Wiley).

O'Brien, N.R., 1987. The effects of bioturbation on the fabric of shale. $J$. Sediment. Petrol., 57:449-455.

O'Brien, N.R., Nakazawa, K., and Tokuhashi, S., 1980. Use of clay fabric to distinguish turbidite and hemipelagic siltstone and silts. Sedimentology, 27:47-61.

Pusch, R., 1973. Influence of organic matter on the geotechnical properties of clays. Natl. Swed. Bldg. Res., 11.

Reynolds, S., and Gorsline, D.S., 1991. Silt microfabric of detrital, deep sea mud(stone)s (California Continental Borderland) as shown by backscattered electron microscopy. In Bennett, R.H., Bryant, W.R., and Hulbert, M.H. (Eds.), Microstructure of Fine-Grained Sediments: From Mud to Shale: New York (Springer-Verlag), 203-211.

Shephard, L.E., and Rutledge, A.K., 1991. Clay fabric of fine-grained turbidite sequences from the southern Nares Abyssal Plain. In Bennett, R.H., Bryant, W.R., and Hulbert, M.H. (Eds.), 1991. Microstructure of FineGrained Sediments: From Mud to Shale: New York (Springer-Verlag), $61-72$.

Swan, A.R.H., and Sandilands, M., 1995. Introduction to Geological Data Analysis: Oxford (Blackwell Scientific).

Torresan, M.E., and Schwab, W.C., 1987. Fabric and its relation to sedimentologic and physical properties of near-surface sediment, Shelikof Strait and Alsek prodelta, Alaska. J. Sediment. Petrol., 57:408-418.

Date of initial receipt: 1 December 1995

Date of acceptance: 10 April 1996

Ms 155SR-235 


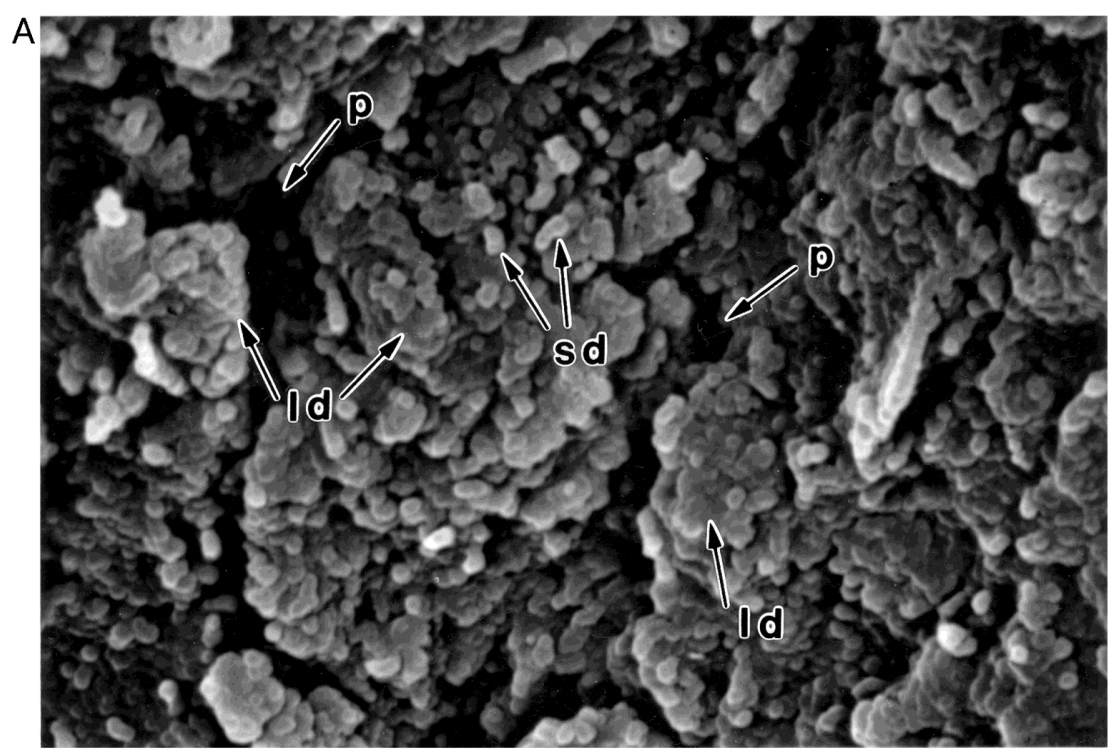

$10 \mu \mathrm{m}$

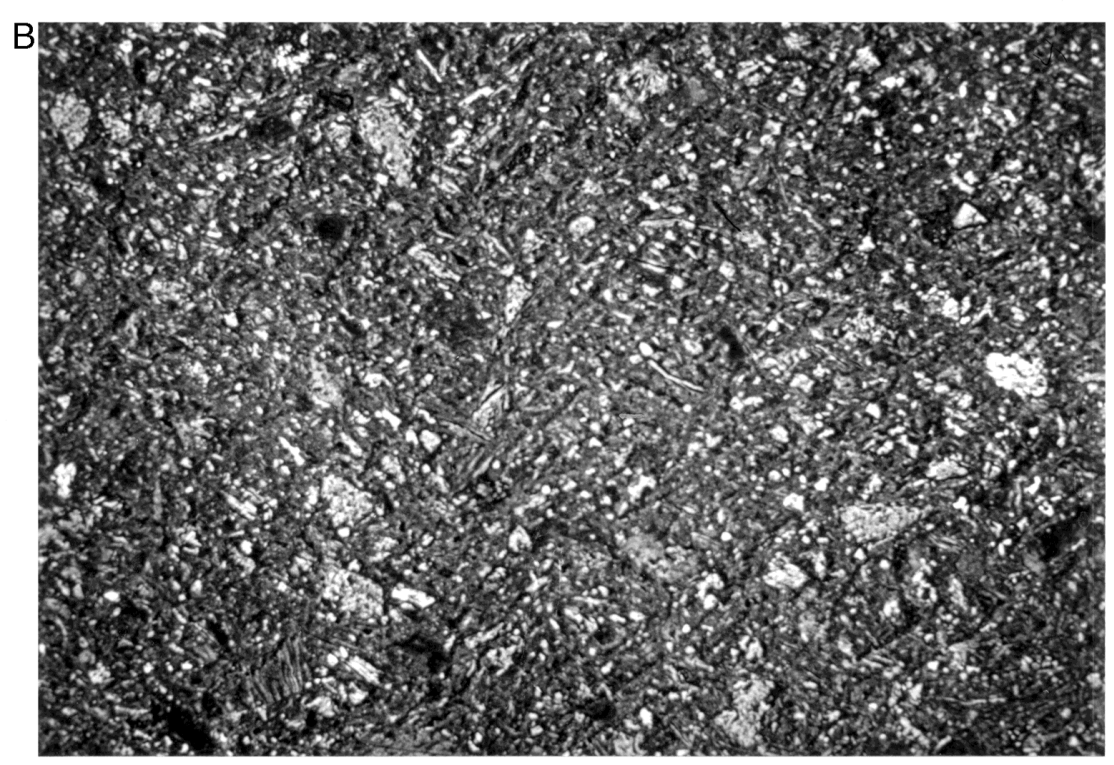

Figure 12. Sample 155-941B-2H-2, 75-77 cm; mass transport; 8.85 mbsf. A. SE micrograph, open fabric with large pores (p) and a combination of small (sd) and large (ld) clay domains. B. BSE micrograph, randomly arranged silt grains floating in a clay matrix. C. Rose diagram for silt particle orientation in BSE micrograph. $s^{2}=0.91$; $\bar{d}_{\max }=15.6 \mu \mathrm{m}$.
C

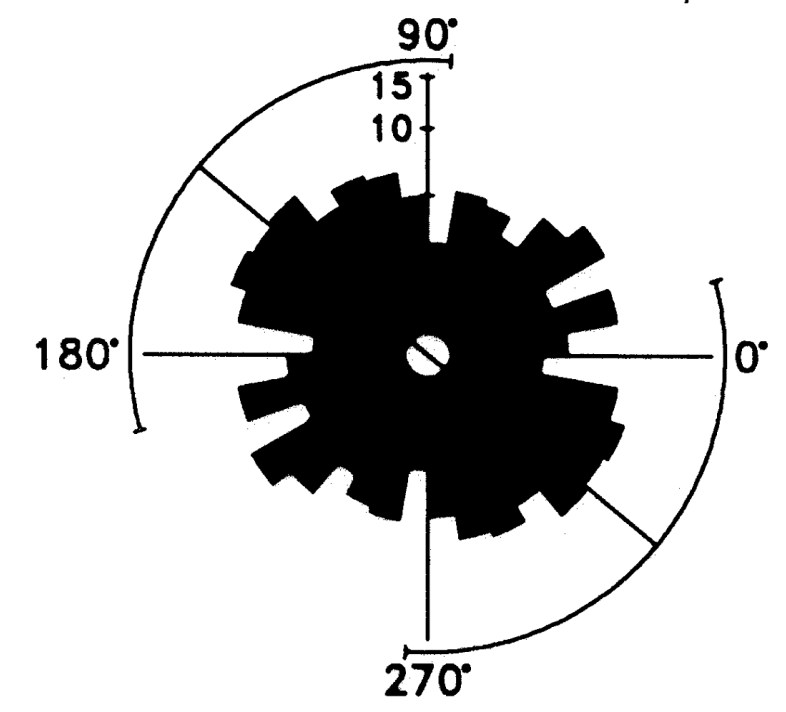



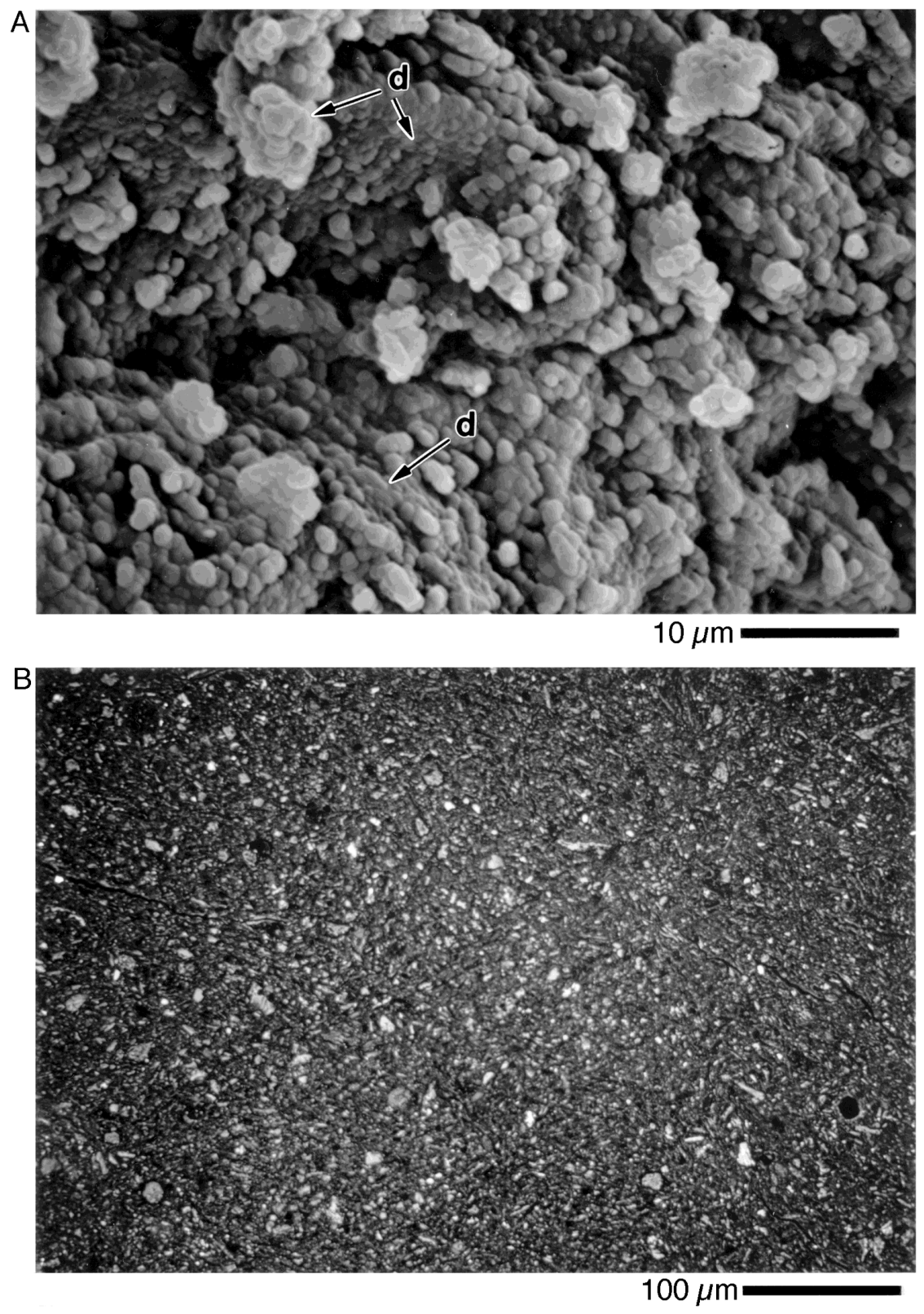

C

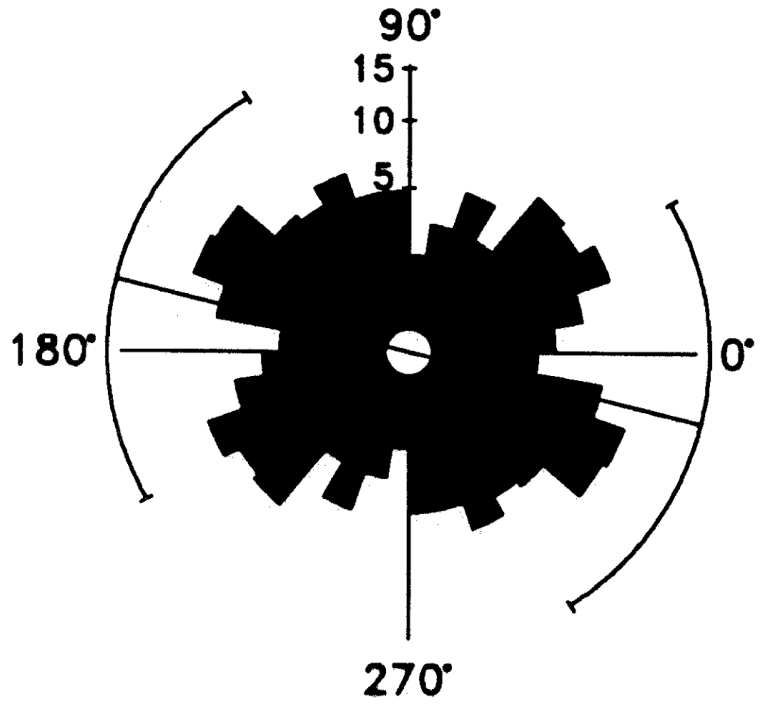

Figure 13. Sample 155-941B-7H-5, 123-125 cm; mass transport; 56.83 mbsf. A. SE micrograph, reduced visible porosity and more compacted domains (d). B. BSE micrograph, randomly arranged fine silt floating in a clay matrix. C. Rose diagram for silt particle orientation in BSE micrograph. $s^{2}=0.88 ; \bar{d}_{\max }=7.3 \mu \mathrm{m}$. 

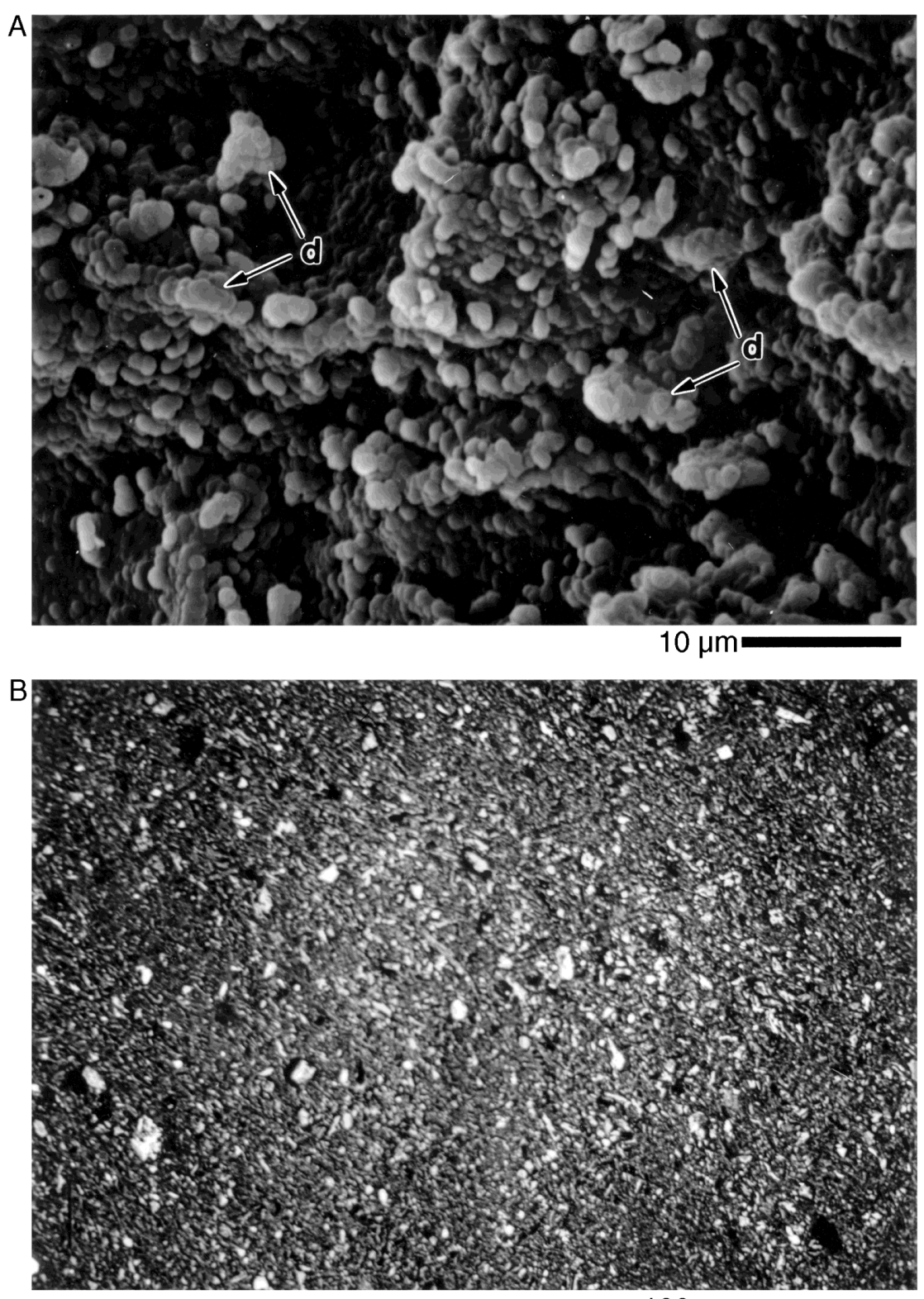

C

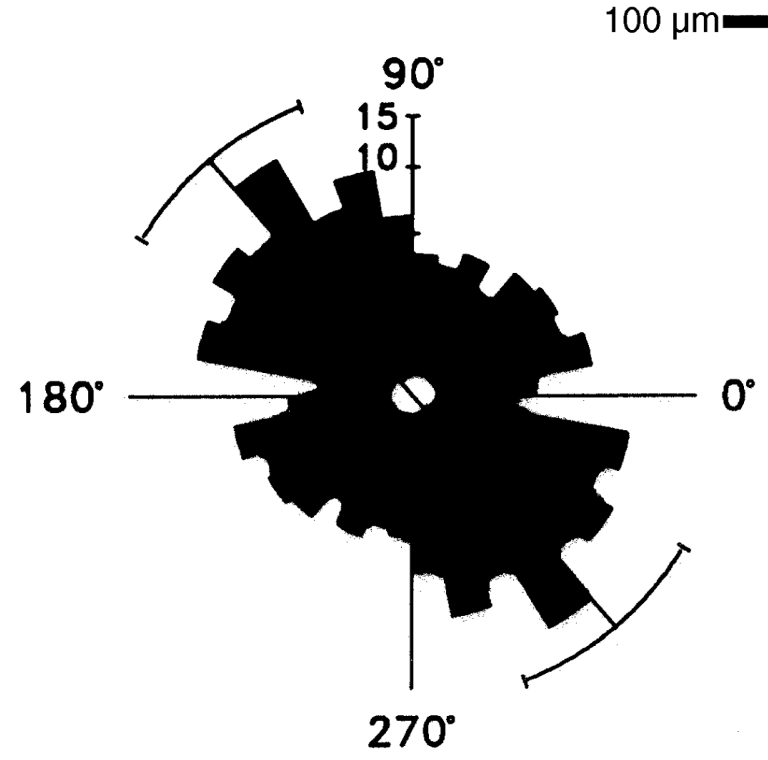

Figure 14. Sample 155-941B-11H-5, 86-88 cm; mass transport; 80.07 mbsf. A. SE micrograph, dense fabric associated with an increase in domain size, an increase in clay particles per domain (d), and a decrease in visible porosity. B. BSE micrograph, silt grains floating in a clay matrix. A rough grain alignment runs from the upper left to the lower right of the image. C. Rose diagram for silt particle orientation in BSE micrograph. $s^{2}$ $=0.74 ; \bar{d}_{\max }=10.2 \mu \mathrm{m}$. 

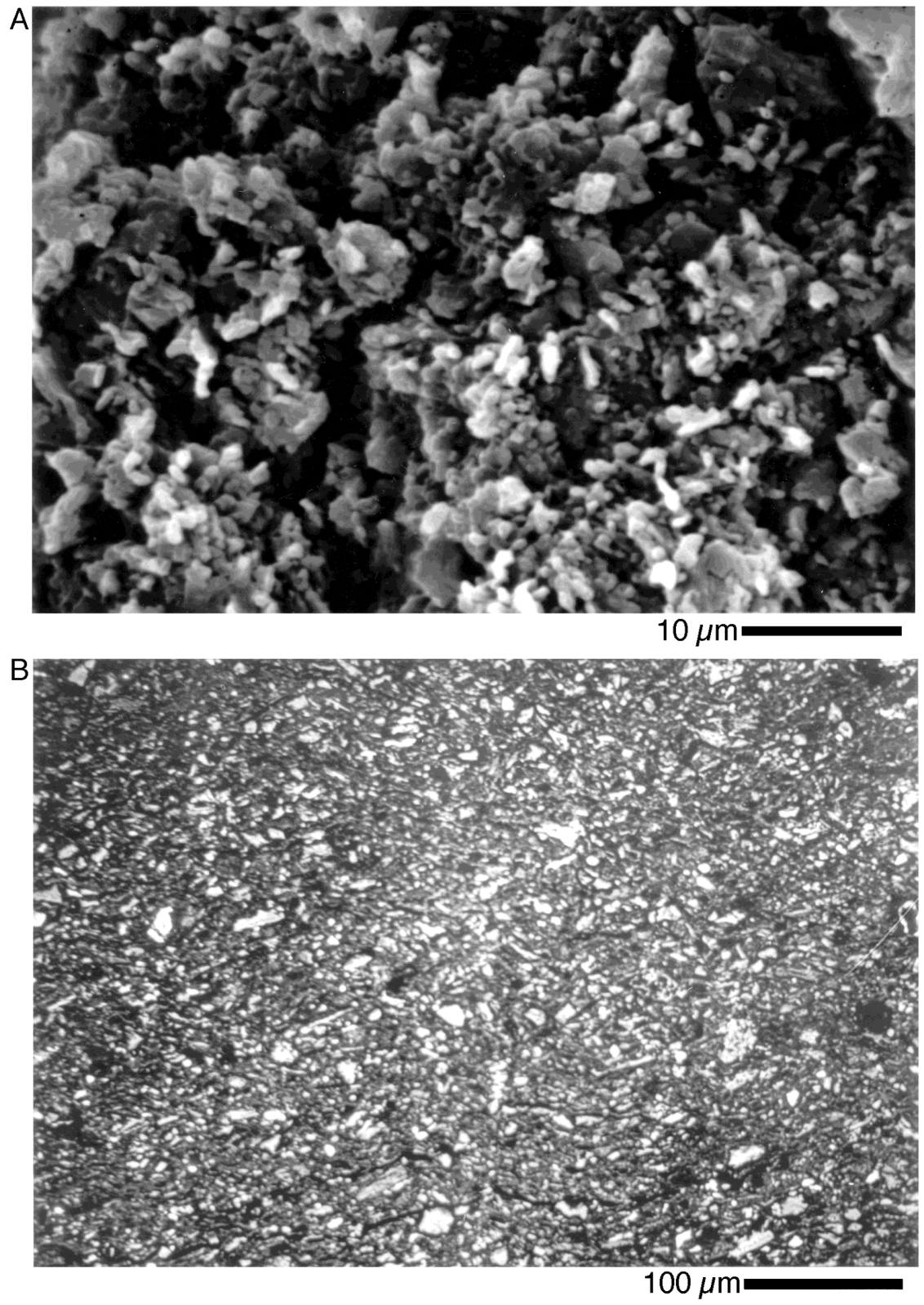

C

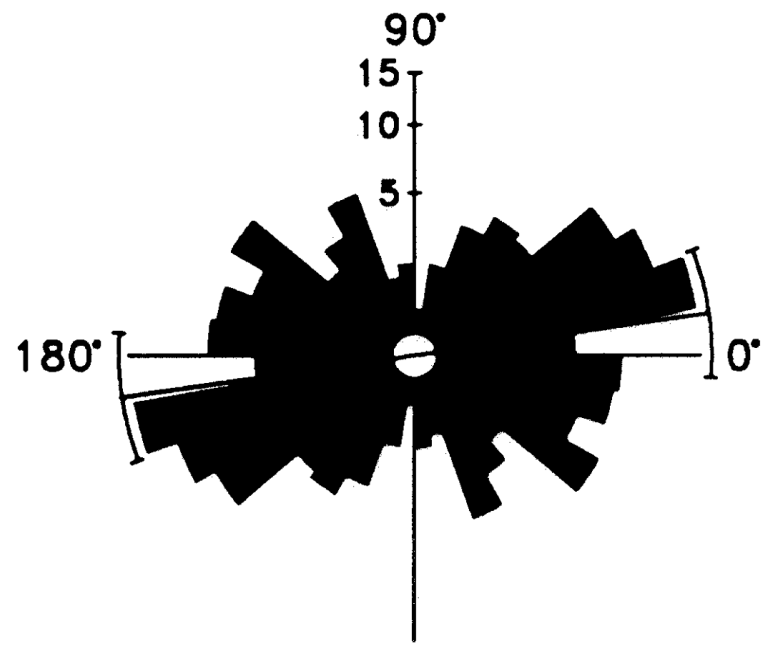

$270^{\circ}$
Figure 15. Sample 155-935A-25X-2, 46-49 cm; mass transport; 220.56 mbsf. A. SE micrograph, dense fabric with little visible porosity. B. BSE micrograph, closely spaced silt grains with a subhorizontal alignment. C. Rose diagram for silt particle orientation in BSE micrograph. $s^{2}=0.62 ; \bar{d}_{\max }=10.3 \mu \mathrm{m}$. 

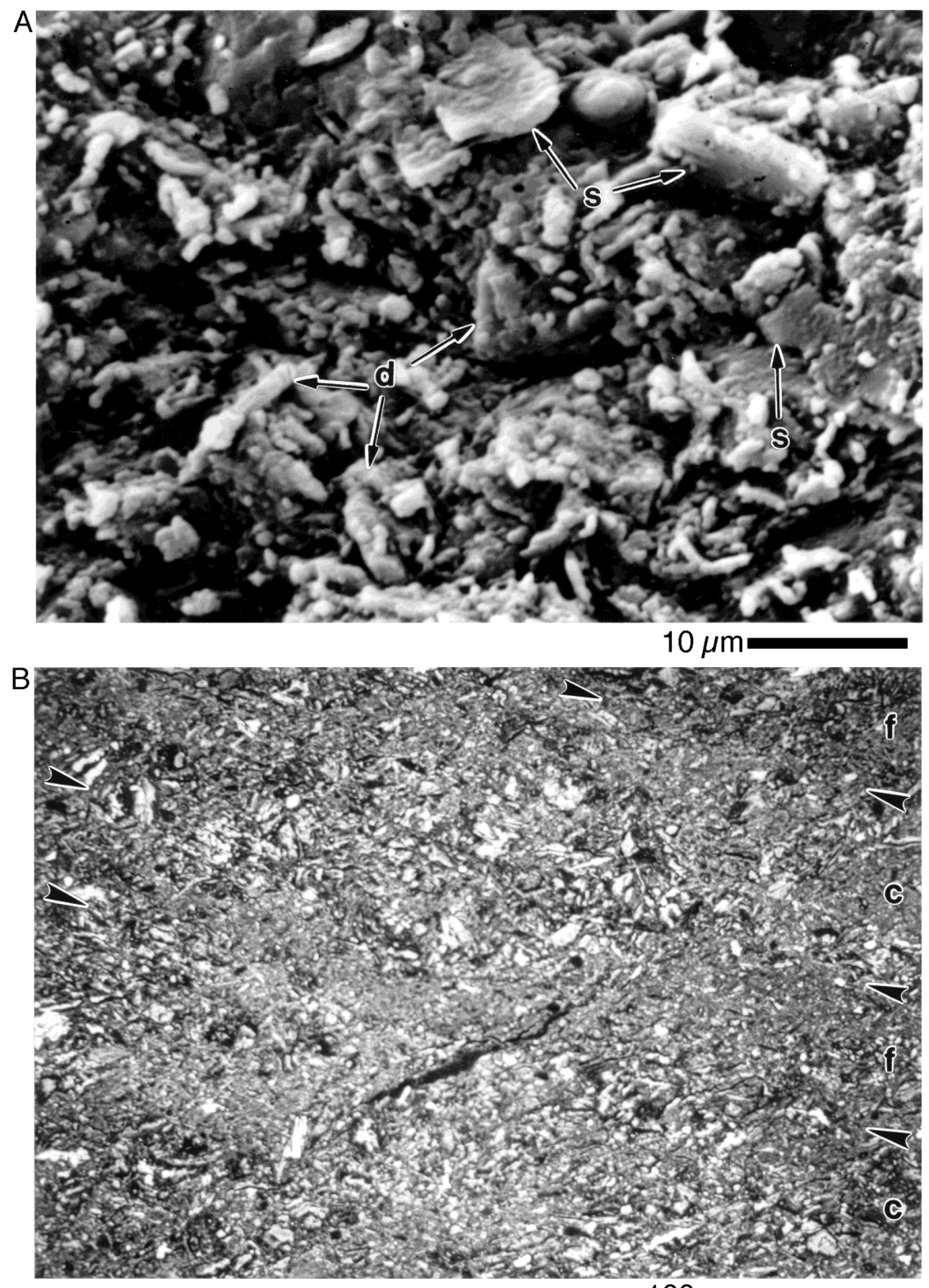

C

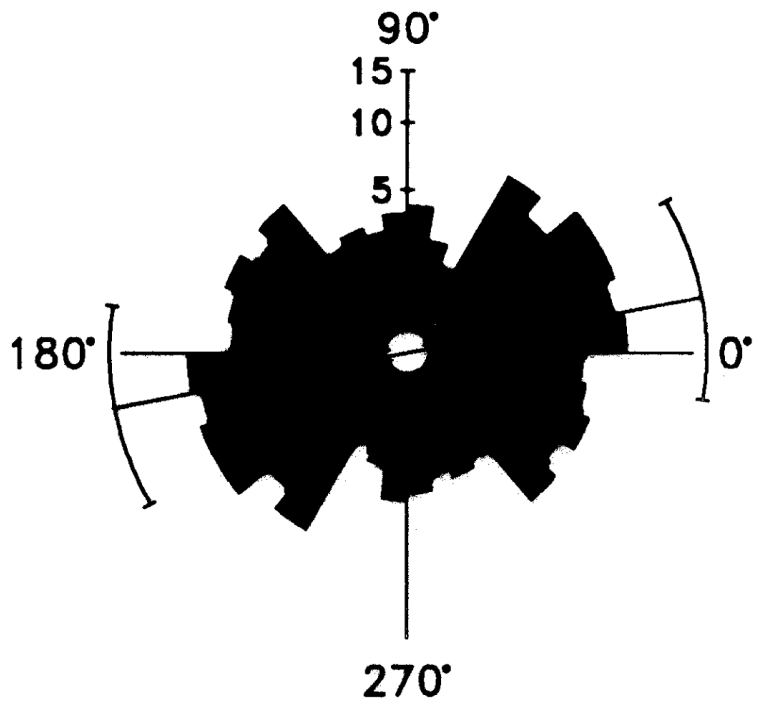

Figure 16. Sample 155-930B-24X-3, 27-29 cm; mass transport; 218.97 mbsf. A. SE micrograph, dense fabric in which clay domains (d) and silt particles (s) are difficult to distinguish. B. BSE micrograph, densely packed silt particles crudely arranged in alternating coarse-grained (c) and fine-grained (f) intervals. C. Rose diagram for silt particle orientation in BSE micrograph. $s^{2}=0.75 ; \bar{d}_{\max }=14.0 \mu \mathrm{m}$. 